OPEN ACCESS

Edited by:

Zamir Punja,

Simon Fraser University, Canada

Reviewed by:

Suha Jabaji.

McGill University, Canada

Xu Wang,

Huazhong Agricultural University,

China

*Correspondence:

Kimberly D. Gwinn

kgwinn@utk.edu

Specialty section:

This article was submitted to

Disease Management,

a section of the journal

Frontiers in Agronomy

Received: 15 October 2021 Accepted: 09 December 2021

Published: 18 January 2022

Citation:

Gwinn KD, Hansen Z, Kelly $\mathrm{H}$ and

Ownley BH (2022) Diseases of Cannabis sativa Caused by Diverse

Fusarium Species.

Front. Agron. 3:796062

doi: 10.3389/fagro.2021.796062

\section{Diseases of Cannabis sativa Caused by Diverse Fusarium Species}

\author{
Kimberly D. Gwinn*, Zachariah Hansen, Heather Kelly and Bonnie H. Ownley \\ Department of Entomology and Plant Pathology, University of Tennessee, Knoxville, TN, United States
}

The potential of species of Fusarium to cause significant economic losses in Cannabis sativa due to plant diseases and mycotoxin residues is the subject of this review. Sixteen species of Fusarium, reported as associated with cannabis production, are classified in six species complexes: Fusarium oxysporum, F. solani, F. incarnatum-equiseti, F. sambucinum, F. tricinctum, and F. fujikuroi. Taxonomy in this genus is the subject of debate, and removal of species in the F. solani Species Complex to the genus, Neocosmospora, has been proposed. Many species associated with C. sativa are also opportunistic pathogens of humans and animals. Species of Fusarium produce a myriad of mycotoxins, including at least three (deoxynivalenol, zearalenone, and fumonisin B) deemed the most important mycotoxins in human and animal foods. These chemicals vary from the very simple chemicals (moniliformin and butanolide) to the structurally complex depsipeptides (beauvericin and enniatin B) and trichothecenes (deoxynivalenol and its acetylated derivatives, diacetoxyscirpenol, and T-2-toxin). The robust strategies for disease management (e.g., exclusion of the pathogen, control of environment, and host resistance) are in development for this new crop and have primarily relied on management systems for other crops. Biopesticides have been labeled for use on C. sativa; however, few efficacy trials have been performed. Host resistance to these pathogens and transmission are also understudied. The new markets for $C$. sativa and its derivative products require knowledge for control of these important fungal diseases to provide safe products for human consumption.

Keywords: Cannabis, hemp, marijuana, Fusarium, mycotoxins, disease control, seed pathology

\section{INTRODUCTION}

Cannabis sativa L. (hemp, marijuana) produces a diverse spectrum of compounds that have been used for centuries as active ingredients in medicinal products; the plant is also a rich source of food (from seed), fiber (both cellulosic and woody from stalks), and oil (from flowers and seeds) (Andre et al., 2016). Both cannabis (referring to drug-containing genotypes) and industrial hemp (with THC levels below $0.3 \%$ ) are cultivated in over 40 countries. Recreational use of cannabis (marijuana) is currently only permitted in Uruguay, Canada, and 12 states in the United States (Adhikary et al., 2021; Punja, 2021b). Other states in the United States have approved cannabis for medicinal use, and cultivation of industrial hemp is now legal in the United States. Legalization for food, fiber, and oil has resulted in the emergence of cannabis and hemp as agronomic crops in many countries, and acceptance of the cannabis plant as a crop has greatly expanded research capacity. It should be noted, however, that in some countries, the cannabis plant and/or its natural products remain illegal. 
In 2019, an estimated 76,730 tons of hempseed were harvested worldwide from $2.3 \times 10^{4}$ hectares, and the crop was valued at over $\$ 126$ million (US), and an estimated 174 million tons of hemp tow and waste was produced on $6.9 \times 10^{4}$ ha (FAOSTAT, 2019). Leaders in acreage of C. sativa are the United States, China, and Canada, but strict government regulations are imposed on production in each of these countries (Mark et al., 2020; Pusiak et al., 2021; Zhao et al., 2021). China produced an estimated $7.14 \times 10^{4}$ tons of hempseed on $1.26 \times 10^{4}$ ha in 2019 (FAOSTAT, 2019). Zhao et al. (2021) reported that acreage in the FAO database was under-reported and that actual acreage was $6.54 \times 10^{4}$ ha in 2020. In the United States, sales in 2020 were $\$ 17.5$ billion, a $46 \%$ increase from 2019 (Yakowicz, 2021). Unlike statistics for other crops, acreage in the United States is estimated from application information on licenses approved for hemp production, but these statistics do not provide a complete picture because not all producers plant all approved acreage (Mark et al., 2020). In October 2021, the United States Department of Agriculture (USDA) National Agricultural Statistics Service (NASS) initiated its first hemp acreage and production survey of producers, putting hemp production on par with other crops. Survey results are used by the USDA-NASS to compile information on the planted and harvested area, yield, production, and value of crops in the United States. In Canada, there were over 1.9 million ha of controlled environment cultivation of cannabis (indoor and greenhouse) and 544 ha of outdoor production in 2020 (Punja, 2021b). Sales of Canadian cannabis were $\$ 2.6$ billion in 2020 (nearly double previous years); these increases were driven by increases in brick-and-mortar retail access, expansion in ecommerce, pricing competitive with the illegal market, and adaptation of retail to the COVID-19 pandemic (Hasse, 2020). In 2019 and 2020, 14\% of Canadians aged 16 years and older reported use of cannabis for medical purposes (Health Canada Cannabis Survey).

Concentration of (-)-trans- $\Delta$ 9-tetrahydrocannabinol (THC), the psychoactive component associated with marijuana strains of C. sativa, is the legal distinction between industrial hemp and marijuana (or drug-type) plants (Adhikary et al., 2021). To be classified as industrial hemp, percent THC (dry weight) must be less than or equal to $0.2 \%$ in most European countries, $0.3 \%$ in Canada, China, and the United States, and 1\% in Switzerland, Uruguay, Columbia, Mexico, and selected Australian states (Adhikary et al., 2021; Zhao et al., 2021). In most countries, plants that exceed these THC limits are considered drug-type plants and are illegal. Despite being defined as two plants with different legal status by governments, the genus Cannabis consists of a single species (C. sativa) that contains three subspecies: subsp. sativa, subsp. indica, and subsp. ruderalis (Zhang et al., 2018b). Others have further divided the subspecies based on THC in dried flowering tops (inflorescences) and domestication status (McPartland, 2018). Although this taxonomy is not universally accepted and some elevate the subspecies to species, in this review, we will use C. sativa for all cannabis and hemp plants and refer to subspecies when this information is available. Commercial cultivars are often a result of interbreeding and hybridization among subspecies (McPartland, 2018), and the

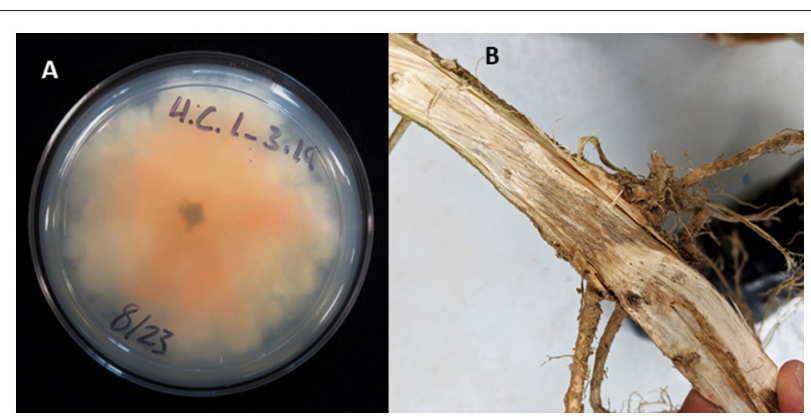

FIGURE 1 | Crown rot in field-grown hemp (Cannabis sativa). (A) Culture of Fusarium isolates with culture morphology typical of F. oxysporum; (B) crown rot caused by Fusarium sp.

genetic background of strains of $C$. sativa are often not disclosed or known, particularly in the marijuana strains.

Pressure from weeds, insects and diseases are among the major challenges in production of C. sativa (reviewed in Punja, 2021c). All parts of the plant at all growth stages are infected by one or more pathogens. Pathogens in the genus Fusarium are among the most destructive pathogens of C. sativa (Figure 1). This is particularly true in the root and vegetative growth phases when infection results in decreased plant quality up to total plant loss. Species of Fusarium also cause significant postharvest losses and produce mycotoxins that further limit the value of the crop. Because, for many countries, the legal status of the plant changed from crop to illegal drug (1950s) and back again in the 2000s (Johnson, 2019), the bulk of literature on C. sativa and Fusarium is written in two distinct time periods (prior to 1960 and after 1990). There are some exceptions to this bimodal distribution, particularly publications reporting the use of $F$. oxysporum $\mathrm{f}$. sp. cannabis as a biological control of the plants (McCain and Noviello, 1985; Noviello et al., 1990). The purpose of this review is to bring together for the first time the reports of all Fusarium species associated with C. sativa and to provide information on mycotoxins produced by these fungi and control of diseases.

\section{FUSARIUM}

The genus Fusarium includes members that cause disease in plants and animals and ones that are not pathogenic. Therefore, a clear taxonomy of the species is needed to ensure correct identification of pathogens. Correct identification is difficult because of the numbers of species with cryptic morphology. The concept of species complex was introduced for Fusarium in recognition that many of these cryptic species are indistinguishable morphologically but have genetic similarity, toxin production, and phenotypic characters (O'Donnell et al., 2018; Summerell, 2019). Recently, two taxonomic structures for the genus have been proposed. The first emphasizes micromorphology and morphology of asexual spores in addition to molecular data (Crous et al., 2021). The second relies on a molecular data-driven taxonomy but considers both end-user and established practice (Geiser et al., 2021). For the current paper, we will use the latter taxonomic structure. 
Fusarium diseases are associated mostly with vascular wilts, but several species can cause seedling damping-off, and rot of crowns, lower stems, roots, and seeds, as well as head and grain blights. The main species involved in root and stem rots are $F$. solani and F. oxysporum. Other species, which have been isolated from hemp, such as F. avenaceum, F. culmorum, F. graminearum, and F. fujikuroi can also cause stalk and root rots. Root, crown, and stem rot diseases caused by Fusarium are distributed worldwide, and can cause significant losses by reducing plant stands, and decreasing growth and yield of many different plant families, including field crops, flowers, and vegetables (Agrios, 2005).

In general, Fusarium solani only produces asexual spores, but some strains may form sexual ascospores (perithecia, ascomycete). There are two main types of asexual spores, microand macroconidia produced by Fusarium. However, some species can produce mesoconidia, which are intermediate in size and can have multiple shapes (Leslie and Summerell, 2006). The types of asexual spores produced, and their abundance varies by species. Microconidia are usually 1-2 celled, with a variety of shapes. Macroconidia are large, often 4-5 celled, and straight to curved with pointed ends. The apical and basal cells of macroconidia have distinctive features. Conidia are produced on mono- or polyphialidic conidiogenous cells (Leslie and Summerell, 2006). Fusarium spp. may also produce thick-walled chlamydospores, which are survival spores that are tolerant to drought and low temperature.

Fusarium spp. can live saprophytically on roots, stems, leaves, flowers, and seed of diseased and dead plants (Summerell et al., 2003). The fungus can survive on seed (internal and external) or as spores or mycelium in dead or infected tissues. The pathogen is disseminated by air, equipment, and water (Agrios, 2005). The roots of plants with fusarium root rot are slightly reddish, becoming dark red to brown. Cracks may be present on the main root while secondary roots are killed by the fungus. Infected plants are stunted and often die with or without wilting (Agrios, 2005). In plants with stem rot, pink or reddish lesions form on the stem at or below the soil line, but usually there is no internal discoloration of the stem. Infections are often initiated at wound sites, but wounds are not necessary for infection, and rots are dry and firm. Fusarium stem and root rots are more severe when plants are stressed by unfavorable temperatures, drought or excess water, and soil conditions that restrict root growth (Bruehl, 1987).

Fusarium causes vascular wilts of a wide range of plants, including vegetables, flowers, field crops (cotton, hemp, tobacco), herbaceous perennial ornamentals, and plantation crops (banana, plantain, coffee, sugarcane) (Agrios, 2005). Fusarium wilts are of worldwide importance and disease severity is favored by warm climates and warm soil temperatures. In the central and southern United States, fusarium wilts can cause severe losses, but in northern climates, Fusarium is limited by temperature to greenhouse crops (Bruehl, 1987).

Most of the vascular wilt fusaria are formae speciales of $F$. oxysporum. Formae speciales (f. sp.) is a subspecific taxonomic rank that refers to a group within a pathogen species that only infects a certain host genus or species (Agrios, 2005). The vascular wilt fusaria are soil inhabitants that survive between crops as mycelium colonizing plant debris in soil, as micro- or macroconidia, or as chlamydospores. Due to the large numbers of spores produced, soil infested with Fusarium may remain so indefinitely (Bruehl, 1987).

Wilt development in other pathosystems is favored by air temperatures of $28^{\circ} \mathrm{C}$, low levels of nitrogen and phosphorus, elevated levels of potassium, low soil $\mathrm{pH}$, short day length, and low light intensity (Agrios, 2005). In other pathosystems, virulence of Fusarium can be enhanced with ammonium nitrogen, and decreased by nitrate nitrogen (Huber and Thompson, 2009). Seedlings infected with fusarium wilt are stunted and eventually wilt and die. Mature leaves of older plants are chlorotic, often only on one side of the plant. Gradually the plant becomes more chlorotic, wilting becomes extensive, and the plant collapses and dies. In the Fusarium wilt/tomato pathosystem, root tips of healthy plants are penetrated directly by germinating Fusarium spores or mycelium can enter the roots via wounds, or at the origin of lateral roots. Mycelium of the fungus grows intercellularly in the root cortex and enters xylem vessels through pits. Once inside the vessels, the fungus produces microconidia that detach and travel upward. Microconidia lodge in the xylem vessels and germinate; the resultant mycelium penetrates the upper wall of the vessel and produces more microconidia that detach and travel upward (Agrios, 2005). The mycelium also grows laterally to penetrate adjacent vessels through pits. The combination of vessel clogging by the fungus, tylosis by the plant (overgrowth of the protoplast of a parenchyma cell into an adjacent xylem vessel), gels, and gums inhibit water uptake by the plant. Accordingly, stomates close, leaves wilt and die, and the plant dies. The fungus then invades the plant extensively and sporulates profusely (Agrios, 2005).

Species determination in Fusarium is difficult, and there are many misidentifications in the literature that have been compounded by changes in taxonomic determinations (O’Donnell et al., 2018; Crous et al., 2021; Geiser et al., 2021). In order to correctly identify species using molecular techniques, care must be taken to use multiple primers for amplification of DNA that will be used in Fusarium identification. A list of recommended PCR primers for amplification of DNA for the identification of Fusarium species is provided by Crous et al. (2021).

\section{FUSARIUM SPECIES AFFECTING CANNABIS AND HEMP}

The 16 species in the genus Fusarium that have been reported as associated with Cannabis sativa are assigned to six of the 23 species complexes proposed by Geiser et al. (2021). We have included all reports of Fusarium associated with C. sativa, even when pathogenicity assays were not performed, in order to provide a complete picture of the current status of the genus on C. sativa. Comparative growth of six species of Fusarium from cannabis plants is shown in Figure 2. The study of Cannabis diseases is in its infancy because the plant has undergone a unique transformation from illegal to an economic product. In order to 


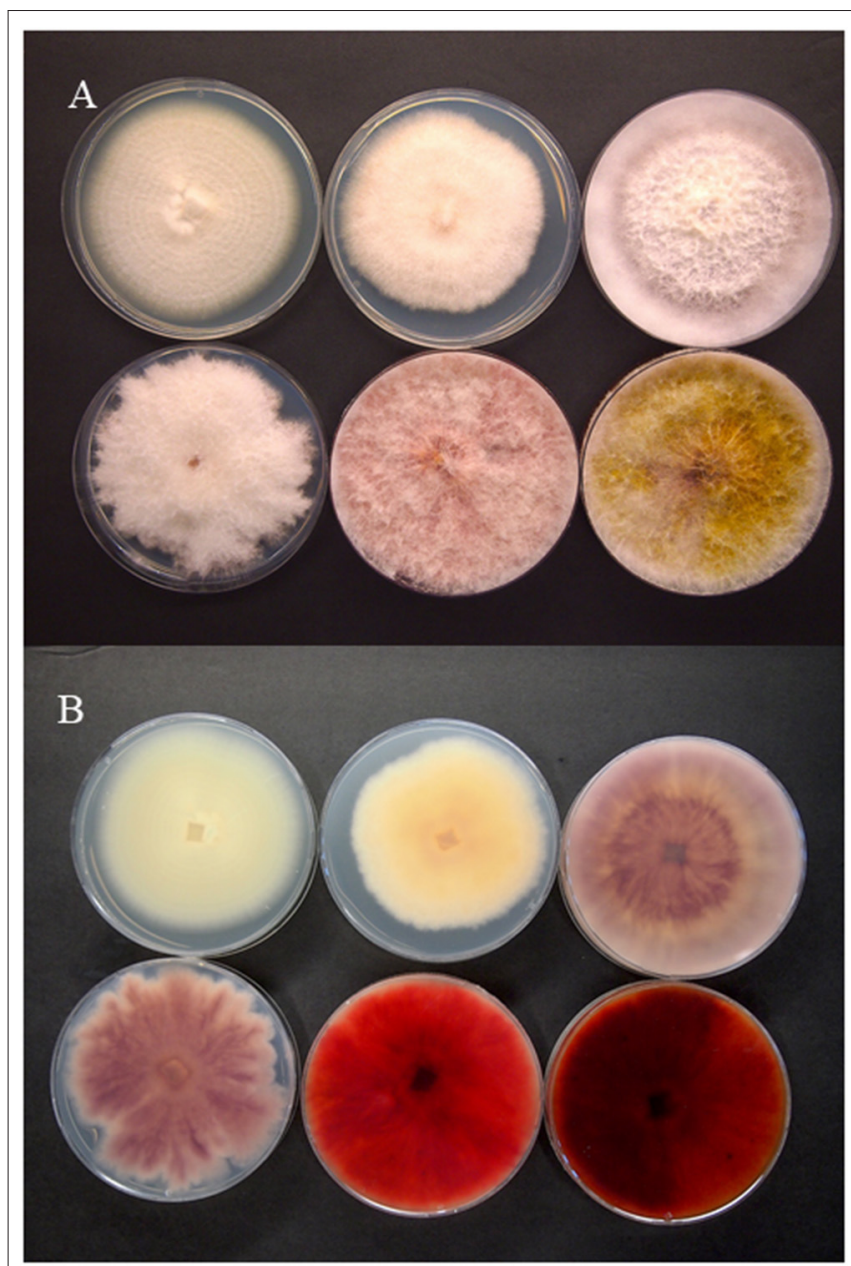

FIGURE 2 | Colony morphology of selected Fusarium species pathogenic on Cannabis sativa. The pathogens are top row, left to right $-F$. solani, F. equiseti, F. oxysporum, and bottom row, left to right $-F$. proliferatum, $F$. sporotrichioides, F. graminearum. (A) Colony viewed from above; (B) underside of the colony Photographs courtesy of Zamir Punja.

manage diseases in these new cropping systems, pathogens must be identified, and effective control strategies must be developed. It is also important to discuss the toxins produced by these Fusarium species, as currently, they are not included in the list of potential causes for concern by regulatory agencies in Canada and the USA.

\section{Fusarium oxysporum Species Complex}

Fusarium oxysporum, the most commonly isolated species of Fusarium, is typically soil borne and is the most economically important species (Lombard et al., 2019). It is the sole member of the FOSC that has been reported associated with $C$. sativa (Table 1). Many isolates of $F$. oxysporum produce beauvericin, bikaverin, enniatin B and moniliformin mycotoxins (Figure 3) (O'Donnell et al., 2018). Fusarium oxysporum is reported to cause wilts and bud, crown, and root rots; symptoms include chlorosis, stunting, and plant death (Figure 4, Table 1). The fungus has been isolated from roots, flowers, and stems of diseased plants grown in the field and in controlled environments. Viable propagules were isolated from $<10 \%$ of the air handling systems in cannabis production facilities tested by Punja (2021c). In addition, F. oxysporum was identified as an endophyte (Punja et al., 2019).

Within the species F. oxysporum, there are over 100 formae speciales (f. sp.), whose descriptions have been historically defined by host range (Summerell, 2019). Two such forms are listed as causal agents of fusarium wilt on C. sativa, F. oxysporum f. sp. cannabis (FoxC) and F. oxysporum f. sp. vasinfectum $($ FoxV). These forms are morphologically identical (Table 2) but are differentiated by host range. The form FoxV can infect important crops such as cotton, mung beans, pigeon peas, rubber trees, alfalfa, soya beans, coffee, and tobacco (McPartland and Hillig, 2004), whereas no host other than cannabis has been described for FoxC (McCain and Noviello, 1985). O'Donnell et al. (2009) identified 256 haplotypes based on combined EF 1- $\alpha$ gene and nuclear ribosomal intergenic spacer (IGS rDNA) region. The type strain of FoxC did not share a haplotype with any of the tested isolates of Fox $\mathrm{V}$ from Gossypium sp. $(n=135)$. However, in field trials, FoxC could easily be distinguished from native $F$. oxysporum based on host range (McCain and Noviello, 1985). In an EF-1 $\alpha$ and ITS concatenated tree analysis, the F. oxysporum isolate collected from coconut coir and rockwool growth substrates in which symptomatic cannabis plants had been grown clustered with isolates from indoor cultivation in British Columbia, Canada, and outdoor cultivation in northern California, USA with sequence identities $>99$ and 95-98\%, respectively (McGehee and Raudales, 2021). These isolates also clustered with isolates that are opportunistic human pathogens, but the type specimen of FoxC did not cluster with the other F. oxysporum isolates. To our knowledge, no new taxonomy has been proposed for FoxC. Sequences for FoxC are available at GenBank [accessions numbers FJ985290 (ITS4 and ITS5) and FJ985497 (EF-1 $\alpha$ )]. Because not all sequences in GenBank are correctly identified or use current taxonomic descriptions, the curated Fusarium databases, Fusarioid-ID (accessible at www.fusarium.org) is recommended (Crous et al., 2021). However, this database does not contain any text field that contains the word cannabis, and FoxC is not included in the USDA Fungal Database (https:// nt.ars-grin.gov/fungaldatabases/). Therefore, the current validity of this f. sp. is unknown, and host range studies have not been conducted to verify the initial observations of McCain and Noviello (1985).

Identification of fusarium wilt of $C$. sativa caused by FoxC is primarily determined by symptoms of the disease. Infection of roots is followed by systemic movement through the plant (McPartland and Hillig, 2004). Symptoms of the disease are first observed on the lower leaves as small, dark, irregular spots combined with mild chlorosis and with leaflet tips curled upward. As the disease progresses systemically through the plant, leaflets and petioles turn yellow-tan, and the dry leaf is retained on the plant. These symptoms are typical for other descriptions of wilts caused by F. oxysporum (Table 1). In plants infected with FoxC, however, symptoms are typically unilateral, and in the field 
TABLE 1 | Disease reported in Cannabis sativa caused by Fusarium oxysporum.

\begin{tabular}{|c|c|c|c|c|}
\hline Initial isolation & Symptoms* & Molecular region/primers & $\begin{array}{l}\text { Pathogenicity } \\
\text { assays }\end{array}$ & Source \\
\hline \multicolumn{5}{|c|}{ Controlled environments (includes greenhouse, hydroponic, and indoor facilities) } \\
\hline Roots and crowns & $\begin{array}{l}\text { Yellowing, crown rot and internal stem } \\
\text { decay. }\end{array}$ & $\begin{array}{l}\text { EF-1 } \alpha / E F 1 \text { and EF2 } \\
\text { ITS1-5.8S-ITS2/UN-UP18 S42 and UN-LO28 } \\
\text { S576B }^{\text {b }}\end{array}$ & Yes & Punja, 2021c \\
\hline $\begin{array}{l}\text { Propagation media } \\
\text { of symptomatic } \\
\text { plants }\end{array}$ & $\begin{array}{l}\text { Root necrosis, chlorosis, and occasional } \\
\text { wilt, reduced root and shoot mass }\end{array}$ & $\begin{array}{l}\text { EF- } 1 \alpha / E F-1 \text { and EF-2 }{ }^{a} ; \text { ITS1-5.8S-ITS2/ITS } 4 \\
\text { and ITS5 }{ }^{\mathrm{C}}\end{array}$ & Yes & $\begin{array}{l}\text { McGehee and Raudales, } \\
2021\end{array}$ \\
\hline Cuttings & Damping-off & $\begin{array}{l}\text { EF- } 1 \alpha / E F 1 \text { and EF2 } \\
\text { ITS1-5.8S-ITS2/UN-UP18 S42 and UN-LO28 } \\
\text { S576B }^{\text {b }}\end{array}$ & Yes & Punja, 2021c \\
\hline Roots & Brown rot of roots and pith browning & ITS1-5.8S-ITS2/ITS1F ${ }^{\mathrm{d}}$ and ITS4 ${ }^{\mathrm{C}}$ & Yes rooted cuttings & Punja et al., 2019 \\
\hline $\begin{array}{l}\text { Flower buds } \\
\text { (preharvest) }\end{array}$ & Brown rot, growth of mycelium on bud & ITS1-5.8S-ITS2/ITS1F ${ }^{d}$ and ITS4 ${ }^{c}$ & Yes rooted cuttings & Punja et al., 2019 \\
\hline Flower buds & Brown rot & ITS1-5.8S-ITS2/ITS1Fe and ITS4 ${ }^{d}$ & Yes, buds & Punja, 2018 \\
\hline Roots & $\begin{array}{l}\text { Browning and rotting of roots (early } \\
\text { vegetative). Pith/vascular discoloration }\end{array}$ & $\begin{array}{l}\text { EF- } 1 \alpha / E F-1 \text { and EF-2 }{ }^{a} \text {; } \\
\text { ITS1-5.8S-ITS2/ITS1F }{ }^{\mathrm{C}} \text { and ITS4 }\end{array}$ & Yes & $\begin{array}{l}\text { Punja and Rodriguez, } \\
2018\end{array}$ \\
\hline \multicolumn{5}{|c|}{ Unspecified or multiple plant production sites } \\
\hline Stem & Wilt & $\begin{array}{l}\text { ITS1-5.8S-ITS2/ITS } 4 \text { and ITS5 }{ }^{\mathrm{C}} \\
\text { EF-1 } \alpha / \text { EF1-728F and EF1-986R e }\end{array}$ & Yes seedlings & Jerushalmi et al., 2020 \\
\hline $\begin{array}{l}\text { Stems with } \\
\text { symptomatic leaves }\end{array}$ & Wilt & $\begin{array}{l}\text { EF-1 } \alpha / E F-1 \text { and EF-2 }{ }^{a} ; \text { RPB2/bRPB2-6F and } \\
\text { bRPB2-7R } ; \beta \text {-tubulin/T1 and T22 }\end{array}$ & Yes & Thiessen et al., 2020 \\
\hline \multicolumn{5}{|l|}{ Field } \\
\hline Crown & $\begin{array}{l}\text { Yellowing foliage, sunken lesions on the } \\
\text { crown }\end{array}$ & ITS1-5.8S-ITS2/ITS1F ${ }^{\mathrm{d}}$ and ITS4 ${ }^{\mathrm{C}}$ & Yes rooted cuttings & Punja et al., 2019 \\
\hline Crown & $\begin{array}{l}\text { Yellowing and wilting followed by total } \\
\text { plant collapse in hot weather. Dark and } \\
\text { sunken crown-internal discoloration }\end{array}$ & $\begin{array}{l}\text { EF- } 1 \alpha / E F-1 \text { and EF-2 }{ }^{a} \text { ITS1-5.8S-ITS2/ITS1F } \\
\text { and ITS4 }{ }^{\mathrm{d}}\end{array}$ & Yes rooted cuttings & Punja et al., 2018 \\
\hline
\end{tabular}

Molecular regions: EF-1 $\alpha$, Translation elongation factor 1- $\alpha$; ITS1-5.8S-ITS2, Internal transcribed spacer region of ribosomal DNA; RPB2, subunit of RNA polymerase II.

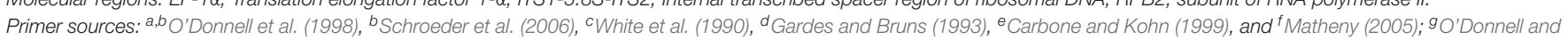

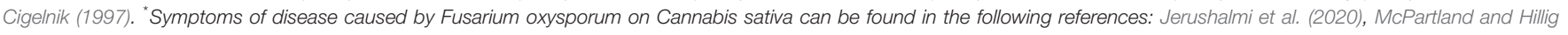
(2004), Punja et al. (2019), and Punja et al. (2018).

when older plants are infected, plants are green on one side and yellow-tan on the other. Roots have a dark-brown discoloration in the vascular system, often with mycelium and microconidia, but the outer surface of the root appears healthy (Noviello and Snyder, 1962). Losses due to fusarium wilt can occur in both industrial hemp and medicinal cannabis (McPartland and Hillig, 2004).

Because of its host specificity, FoxC has been studied as a biocontrol for C. sativa (Hildebrand and McCain, 1978; McCain and Noviello, 1985; Tiourebaev et al., 2001). In Italy, hemp production was eliminated in the region where the type isolate of the fungus was collected, and cultivars that were commonly grown and susceptible to the disease, are no longer available (McCain and Noviello, 1985). In field trials, mortality in inoculated fields was 50\%; the same inoculum was tested for pathogenicity against more than 50 plant hosts, and none were infected. Crop plants following $C$. sativa in fields that were infested did not become infected. In the Chu Valley of southeast Kazakhstan, C. sativa (ditchweed) is a difficult to control weed species. Isolates collected in the region were evaluated on ditchweed for host specificity, then mycoherbicide potential was determined. The most effective isolate infected
$50-66 \%$ of ditchweed plants depending upon the year tested (Tiourebaev et al., 2001).

\section{Fusarium solani Species Complex}

Approximately two-thirds of all fusarioses of animals are caused by members of the FSSC. There are also important plant pathogens in this complex, and some species are pathogenic to both animals and plants (e.g., F. falciforme) (O'Donnell et al., 2008). Crous et al. (2021) reassigned species in FSSC to the genus Neocosmospora. Geiser et al. (2021) assigned the more than 80 species in the FSSC to three major clades. Three species of Fusarium that cause disease in C. sativa (F. solani, F. falciforme, F. lichenicola) (Figure 4, Table 3) are members of Clade 3, the largest clade of the FSSC (O'Donnell et al., 2020; Geiser et al., 2021). Two other members of this clade that are typically human pathogens, F. petroliphilium and $F$. keratoplasticum (Short et al., 2013) were isolated from C. sativa commercial farms (Jerushalmi et al., 2020). Although the species in FSSC do not typically produce mycotoxins, a study that linked taxonomy and mycotoxin production reported that one isolate out of five produced beauvericin (O’Donnell, 2018). Some isolates of F. solani produce cyclosporins, immunosuppressive 

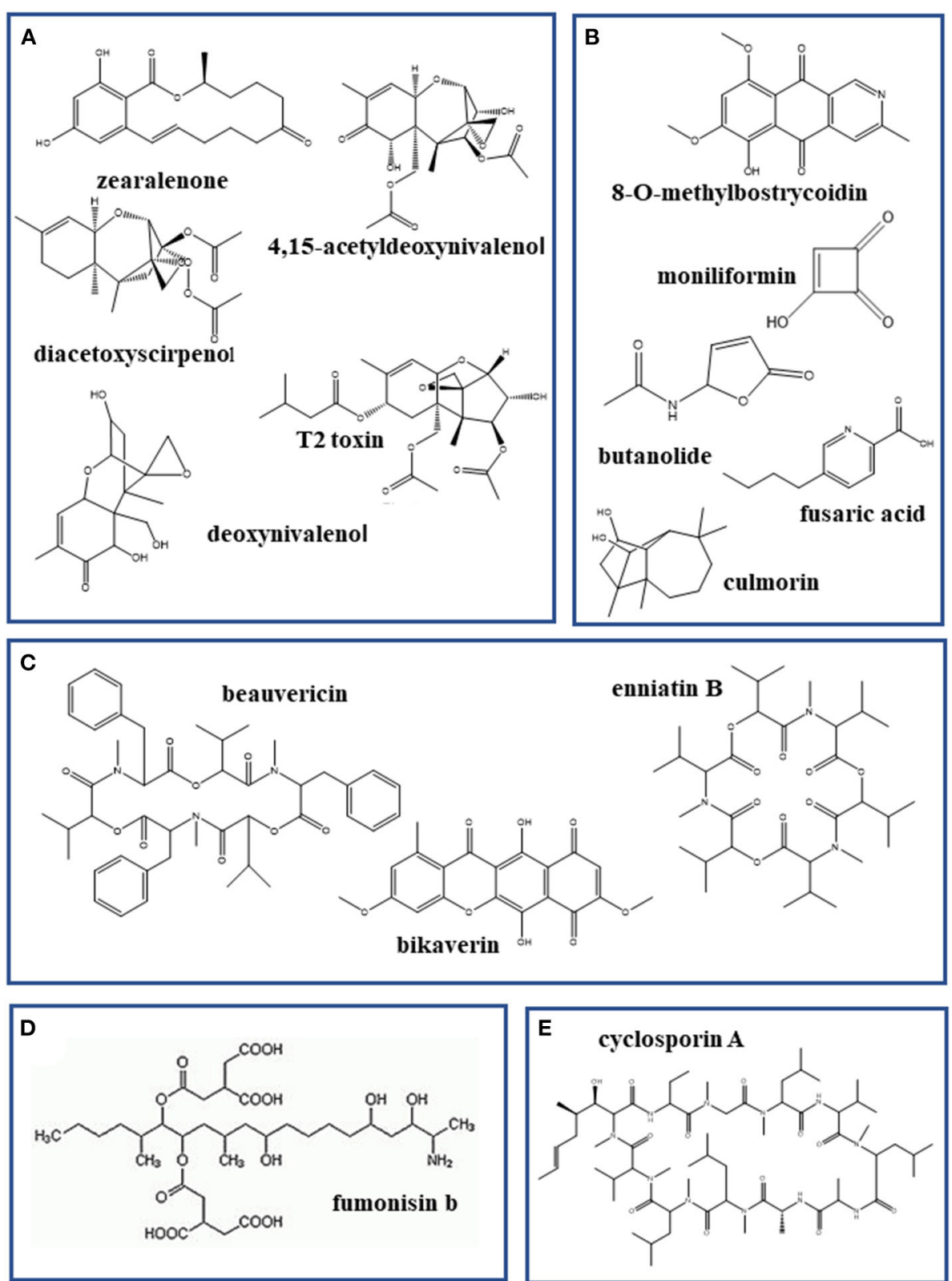

FIGURE 3 | Selected mycotoxins produced by species of Fusarium pathogenic on Cannabis sativa. (A) Trichothecene mycotoxins; (B) emerging mycotoxins; (C) emerging mycotoxins with known ionophoric activity; (D) fumonisins; and (E) cyclosporine.

peptides with antimicrobial and antifungal activity. In Israel, $F$. oxysporum and $F$. solani were among the most prevalent pathogens isolated from commercial farms in summer months, and in pathogenicity assays, $80 \%$ of inoculated seedlings developed wilt symptoms and died (Jerushalmi et al., 2020). Both F. solani and F. lichenicola were isolated from symptomatic plants in commercial greenhouses in Canada (Punja et al., 2021). The species were differentiated based on partial gene sequences for EF- $1 \alpha$, rDNA ITS1-5.8S-ITS2, RPB2, and $\beta$-tubulin with various primers, and they also differed in morphology of colonies and macroconidia (Table 1). Isolates of F. lichenicola produced a yellow-brown pigment that was absent in F. solani. Tolerance of temperatures $>30^{\circ} \mathrm{C}$ was higher in F. solani than $F$. lichenicola. Both species were isolated from vegetative and flowering plants, but only $F$. solani was isolated from vegetative cuttings (Punja et al., 2021). In several studies, F. solani was more aggressive and/or caused more severe symptoms (bud decay or root mass reduction) than other species (Punja, 2018; Punja et al., 2018, 2019). Fusarium javanicum f. sp. radicicola (current accepted names are $F$. solani or $N$. solani) was listed as a pathogen of hemp seed or seedlings, but disease severity and incidence were less than F. oxysporum or 


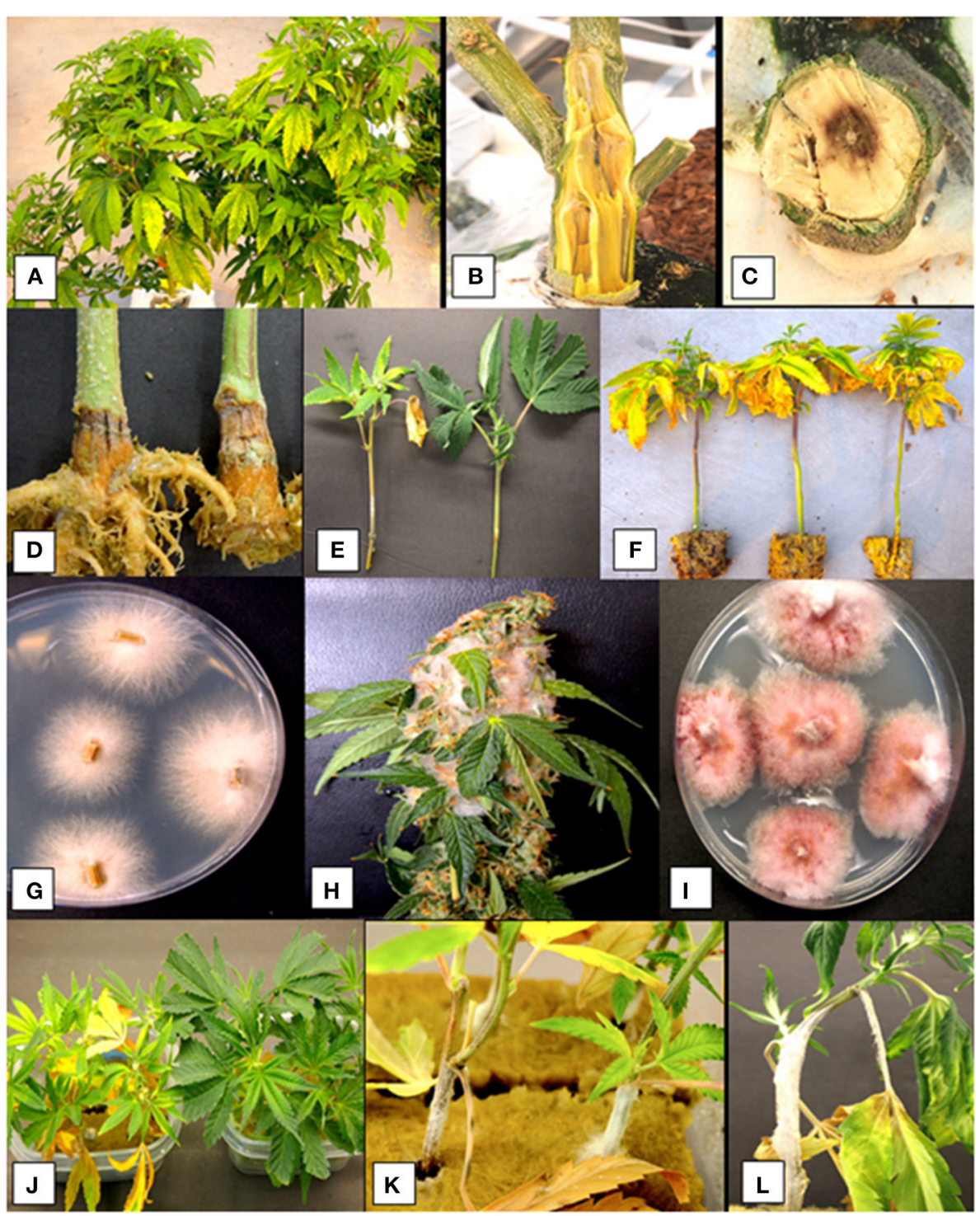

FIGURE 4 | Infection of greenhouse grown cannabis plants by Fusarium species. (A) Yellowing symptoms on stock plants. (B) Crown infection and decay caused by F. solani. (C) Pith necrosis caused by F. proliferatum. (D) Crown rot caused by F. oxysporum. (E) Diseased cutting (left) compared to healthy one (right) caused by F. oxysporum. (F) Symptoms of yellowing on rooted cuttings caused by F. oxysporum. (G) Colonies of F. oxysporum recovered from symptomatic tissues. (H) Flower infection caused by F. sporotrichiodes. (I) Recovery of colonies of F. sporotrichiodes from diseased flower. (J-L) Pathogenicity tests with F. oxysporum on cannabis cuttings showing development of symptoms of yellowing and mycelial growth. Photographs courtesy of Zamir Punja.

F. avenaceum f. sp. herbarum (current name F. avenaceum) (Zelenay, 1960).

\section{Fusarium Incarnatum-Equiseti Species Complex}

Although FIESC is one of the most species-rich complexes, Fusarium equiseti is the sole member of the FIESC that has been associated with $C$. sativa. Some isolates of $F$. equiseti cause disease, whereas others promote plant growth and are used as microbial pesticides for other Fusarium species [e.g., Fusarium wilt of tomato (Horinouchi et al., 2011)]. Mycotoxin production by $F$. equiset $i$ is well documented; isolates in the O'Donnell et al. (2018) study produced trichothecene mycotoxins (diacetoxyscirpenol, 4,15-diacetylnivalenol) (Figure 3A) and fusaric acid. The fungus has been isolated from flowers and stems of symptomatic plants in both indoor and outdoor production of C. sativa (Table 2). In pathogenicity assays, flower buds developed bud rot (Punja et al., 2018), seedlings developed wilt (Jerushalmi et al., 2020), and light-brown circular lesions with dark margins that became gray-brown with age were produced on leaves (Thiessen et al., 2020). Isolates collected from symptomatic plants in outdoor production in northern California were not pathogenic (Punja et al., 2018). 
TABLE 2 | Descriptions of macro- and micro-morphological characters of Fusarium spp. isolated from Cannabis.

\begin{tabular}{|c|c|c|c|c|}
\hline Fusarium species & Colony morphology & Macroconidia & Microconidia & Source \\
\hline \multicolumn{5}{|c|}{ Fusarium oxysporum species complex (FOSC) } \\
\hline F. oxysporum & $\begin{array}{l}\text { White aerial mycelium, purple } \\
\text { pigmentation underneath }\end{array}$ & $\begin{array}{l}\text { Hyaline, falciforme, septate }(4-7) \text {, } \\
49-61 \times 9.6-10.8 \mu \mathrm{m}\end{array}$ & & Thiessen et al., 2020 \\
\hline \multicolumn{5}{|l|}{$\begin{array}{l}\text { F. oxysporum f. } \\
\text { sp. vasinfectum }\end{array}$} \\
\hline \multicolumn{5}{|c|}{ Fusarium solani species complex (FSSC) } \\
\hline F. solania & $\begin{array}{l}\text { White aerial mycelium, no } \\
\text { pigmentation underneath }\end{array}$ & $\begin{array}{l}\text { Falciform, septate (3-4), 23.8-29.2 } \\
\times 3.2-5.0 \mu \mathrm{m}\end{array}$ & $\begin{array}{l}\text { Oval, ellipsoid and fusiform, } \\
\text { septate }(0-1), 9.8-12.7 \times \\
2.6-4.1 \mu \mathrm{m}\end{array}$ & $\begin{array}{l}\text { Punja et al., } 2021 \text { Sorrentino } \\
\text { et al., } 2019\end{array}$ \\
\hline F. lichenicola & $\begin{array}{l}\text { White aerial mycelium, } \\
\text { yellowish-brown pigment with } \\
\text { streaks of violet-blue underneath }\end{array}$ & $\begin{array}{l}\text { Cylindrical with one end tapered, } \\
\text { septate }(1-3), 32.8 \times 3.27 \mu \mathrm{m}\end{array}$ & Not described & Punja et al., 2021 \\
\hline \multicolumn{5}{|c|}{ Fusarium incarnatum-equiseti species complex (FIESC) } \\
\hline F. equiseti & $\begin{array}{l}\text { White mycelium with fuchsia } \\
\text { pigment underneath }\end{array}$ & $\begin{array}{l}\text { Falciforme, septate }(3-7), 22.2 \times \\
6.8 \mu \mathrm{m}\end{array}$ & & Thiessen et al., 2020 \\
\hline \multicolumn{5}{|c|}{ Fusarium sambucinum species complex (FSAMSC) } \\
\hline F. graminearum & $\begin{array}{l}\text { White-pink mycelia, fuchsia to dark } \\
\text { red pigment underneath }\end{array}$ & $\begin{array}{l}\text { Falcate, septate }(5-6), 35.4-49.7 \times \\
3.4-5.8 \mu \mathrm{m}\end{array}$ & None produced & $\begin{array}{l}\text { Yulfo-Soto et al., } 2021 \\
\text { Thiessen et al., } 2020\end{array}$ \\
\hline F. brachygibbosum & $\begin{array}{l}\text { White-pink mycelia, fuchsia to dark } \\
\text { red pigment underneath }\end{array}$ & Not reported & Not reported & \\
\hline \multicolumn{5}{|c|}{ Fusarium fujikuroi species complex (FFSC) } \\
\hline F. proliferatum & $\begin{array}{l}\text { White mycelium with a range of } \\
\text { pigmentation underneath. Some } \\
\text { isolates produced an intense } \\
\text { purple pigment. }\end{array}$ & Not reported & Produced in chains & Punja, 2021d \\
\hline
\end{tabular}

${ }^{a}$ Crous et al. (2021) reassigned these species to the genus, Neocosmospora.

\section{Fusarium sambucinum Species Complex}

Three members of the FSAMSC ( $F$. graminearum, $F$. brachygibbosum, F. sporotrichioides), have been reported to cause disease in C. sativa (Table 5). Viable propagules from F. sporotrichioides were found in air handling systems of commercial Cannabis facilities (Punja, 2021a). Detached buds inoculated with mycelial plugs of F. sporotrichioides had extensive mycelial colonization and caused tissue necrosis (Figure 4) (Punja, 2021a). Fusarium culmorum was reported from samples collected across New Brunswick (Cormier et al., 2019). Both F. graminearum and F. sporotrichioides were recently reported in Kentucky field grown hemp (Ricciardil et al., 2021; Smith et al., 2021): F. sporotrichioides was isolated from field grown hemp in Tennessee (Barboza et al., 2021). Mycotoxins produced by F. sporotrichioides include beauvericin, butanolide, and T2-Toxin, and F. graminearum is a well-known producer of beauvericin, culmorin, and trichothecene mycotoxins (15acetyldeoxynivalenol, 3-acetyldeoxynivalenol, and zearalenone) (O’Donnell et al., 2018). Fusarium brachygibbosum was not included in the study (O'Donnell et al., 2018).

\section{Fusarium tricinctum Species Complex}

Two species classified in the FTSC, F. avenaceum and $F$. tricinctum, were isolated from $C$. sativa plants with severe wilting and yellowing and stem cankers (Punja and $\mathrm{Ni}$,
2021). Fusarium avenaceum var. herbarum caused seed and seedling disease intermediate to $F$. oxysporum and F. solani (Zelenay, 1960). Members of FTSC produced enniatin B and moniliformin mycotoxins (O'Donnell et al., 2018).

\section{Fusarium fujikuroi Species Complex}

Cannabis plants infected with $F$. proliferatum developed wilt (seedlings) (Jerushalmi et al., 2020), damping-off in rooted cuttings, leaf yellowing and necrosis, defoliation, crown rot, and internal browning/blackening of pith (vegetative and flowering stages of 15 cannabis strains) (Figure 4) (Punja, 2021d). Fusarium proliferatum was isolated from stems and crown tissues of vegetative and flowering plants as well as postharvest flower buds and from air samples of the production facility (Punja, 2021d). In pathogenicity assays, inoculation with F. proliferatum resulted in colonization of both stems and leaves, leaves were necrotic and wilted, and in some plants, wilting of the entire plant occurred. Fusarium verticillioides (currently F. fujikuroi) was collected from an infected plant (Jerushalmi et al., 2020), but pathogenicity was not determined. Fusarium fujikuroi was recently isolated from field grown hemp in Virginia (Chawla et al., 2021). Members of the FFSC are notorious mycotoxin producers. Both of the aforementioned species produce bikaverin, fumonisins, and 8-O-methylbostrycoidin. 
TABLE 3 | Diseases reported in C. sativa caused by members of the Fusarium solani species complex (FSSC)

\begin{tabular}{|c|c|c|c|c|c|}
\hline Species & Initial isolation & Symptoms* & Molecular region/primers & $\begin{array}{l}\text { Pathogenicity } \\
\text { assays }\end{array}$ & Source \\
\hline \multicolumn{6}{|c|}{ Controlled environments (includes greenhouse, hydroponic, and indoor facilities) } \\
\hline \multirow[t]{4}{*}{ F. solani } & $\begin{array}{l}\text { Root segments, } \\
\text { crown tissues, } \\
\text { vegetative } \\
\text { cuttings }\end{array}$ & $\begin{array}{l}\text { Yellowing, crown rot and } \\
\text { root-browning }\end{array}$ & $\begin{array}{l}\text { EF-1 } \alpha / E F 1 \text { and EF2 }{ }^{\mathrm{b}} \text {; } \\
\text { ITS1-5.8S-ITS2/UN-UP18 S42 and } \\
\text { UN-LO28 S576B }\end{array}$ & Yes & Punja and Ni, 2021 \\
\hline & Roots & $\begin{array}{l}\text { Brown rot of roots and pith } \\
\text { browning. More severe browning } \\
\text { than F. oxysporum }\end{array}$ & ITS1-5.8S-ITS2/ITS1F $F^{e}$ and ITS4 ${ }^{d}$ & $\begin{array}{l}\text { Yes, rooted } \\
\text { cuttings }\end{array}$ & Punja et al., 2019 \\
\hline & $\begin{array}{l}\text { Pre-harvest } \\
\text { flower buds }\end{array}$ & $\begin{array}{l}\text { Brown rot, more severe symptoms } \\
\text { than } F \text {. oxysporum and } F \text {. equiseti } \\
\text { isolates }\end{array}$ & ITS1-5.8S-ITS2/ITS1Fe and ITS4 ${ }^{d}$ & Yes, flower buds & Punja, 2018 \\
\hline & Roots & Root and crown infections & $\begin{array}{l}E F-1 \alpha / E F-1 \text { and } E F-2^{b} ; \\
\text { ITS1-5.8S-ITS2/ITS1Fe and ITS } 4^{d}\end{array}$ & Yes & $\begin{array}{l}\text { Punja and Rodriguez, } \\
2018\end{array}$ \\
\hline F. lichenicola & $\begin{array}{l}\text { Root segments, } \\
\text { crown tissues }\end{array}$ & $\begin{array}{l}\text { Yellowing, crown rot and } \\
\text { root-browning }\end{array}$ & $\begin{array}{l}\text { EF-1 } \alpha / E F 1 \text { and EF2 }{ }^{\mathrm{b}} \text {; } \\
\text { ITS1-5.8S-ITS2/UN-UP18 S42 and } \\
\text { UN-LO28 S576B }{ }^{\mathrm{c}}\end{array}$ & Yes & Punja et al., 2021 \\
\hline \multicolumn{6}{|c|}{ Unspecified or multiple } \\
\hline F. solani & Stem & Wilt & $\begin{array}{l}\text { ITS1-5.8S-ITS2/ITS } 4 \text { and ITS5 }{ }^{d} \text {; } \\
\text { EF-1 } \alpha / E F 1-728 F \text { and EF1-986R }\end{array}$ & $\begin{array}{l}\text { Yes, wilting of } \\
\text { seedlings }\end{array}$ & Jerushalmi et al., 2020 \\
\hline F. falciforme & Stem & Wilt & $\begin{array}{l}\text { ITS1-5.8S-ITS2/ITS } 4 \text { and ITS5 }{ }^{d} \text {; } \\
\text { EF-1 } \alpha / E F 1-728 F \text { and EF1-986R }\end{array}$ & No & Jerushalmi et al., 2020 \\
\hline \multicolumn{6}{|l|}{ Field } \\
\hline F. solani & $\begin{array}{l}\text { Crown outer } \\
\text { bark, cortical } \\
\text { and vascular } \\
\text { tissues }\end{array}$ & $\begin{array}{l}\text { Yellowing and wilting followed by } \\
\text { total plant collapse in hot weather. } \\
\text { Dark and sunken crown with } \\
\text { discoloration. Root mass } \\
\text { reduction-most aggressive of the } \\
\text { isolated Fusarium species }\end{array}$ & $\begin{array}{l}\mathrm{EF}-1 \alpha / \mathrm{EF}-1 \text { and } E F-2^{\mathrm{b}} \text {; } \\
\text { ITS1-5.8S-ITS2/ITS1Fe and ITS4 }\end{array}$ & $\begin{array}{l}\text { Yes, rooted } \\
\text { cuttings }\end{array}$ & Punja et al., 2018 \\
\hline
\end{tabular}

Molecular regions: EF-1 $\alpha$, Translation elongation factor 1- $\alpha$; ITS1-5.8S-ITS2, Internal transcribed spacer region of ribosomal DNA.

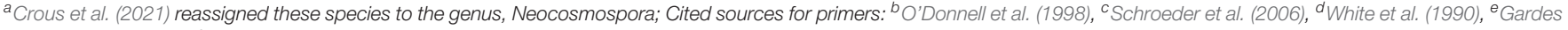
and Bruns (1993) and ${ }^{f}$ Carbone and Kohn (1999).

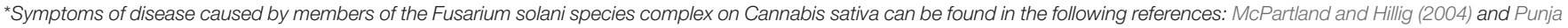
et al. (2018).

TABLE 4 | Diseases reported in C. sativa caused by Fusarium equiseti.

\begin{tabular}{|c|c|c|c|c|}
\hline Initial isolation & Symptoms* & Molecular markers & Pathogenicity assays & Source \\
\hline \multicolumn{5}{|c|}{ Controlled environments (includes greenhouse, hydroponic, and indoor facilities) } \\
\hline $\begin{array}{l}\text { Pre-harvest flower } \\
\text { buds. }\end{array}$ & Brown rot & ITS1-5.8S-ITS2/ITS1Fa and ITS4 ${ }^{\mathrm{b}}$ & Yes, flower buds & Punja, 2018 \\
\hline \multicolumn{5}{|c|}{ Unspecified or multiple } \\
\hline & $\begin{array}{l}\text { Foliar blight, mycelium completing } \\
\text { covering inflorescences and sugar } \\
\text { leaves }\end{array}$ & $\begin{array}{l}\text { ITS1-5.8S-ITS2/ITS } 4 \text { and ITS5 } 5^{\mathrm{b}} \text {; } \\
\text { EF-1 } \alpha / E F 1-728 F \text { and EF1-986R }\end{array}$ & Yes, detached flowers & Jerushalmi et al., 2020 \\
\hline $\begin{array}{l}\text { Flowers and leaves } \\
\text { of plants }\end{array}$ & Foliar and flower blight & $\begin{array}{l}\text { EF- } 1 \alpha / E F-1 \text { and EF-2 }{ }^{c} \text {; } \\
\text { RPB2/bRPB2-6F and bRPB2-7R }{ }^{d} \text {; } \\
\beta \text {-tubulin/T1 and T22 }\end{array}$ & Yes & Thiessen et al., 2020 \\
\hline
\end{tabular}

\section{Field}

Crown outer bark Isolates were not pathogenic even though isolated from symptomatic plants
$\mathrm{EF}-1 \alpha / \mathrm{EF}-1$ and $\mathrm{EF}-2^{\mathrm{b}}$; ITS1-5.8S-ITS2/ITS1Fe and ITS4d

Molecular regions: EF-1 $\alpha$, Translation elongation factor 1- $\alpha$; ITS1-5.8S-ITS2, Internal transcribed spacer region of ribosomal DNA; RPB2, subunit of RNA polymerase II.

a Gardes and Bruns (1993), 'b White et al. (1990), ' ${ }^{\circ} \mathrm{O}^{\prime}$ Donnell et al. (1998), 'd Matheny (2005), and ' O'Donnell and Cigelnik (1997).

*Symptoms of disease caused by Fusarium equiseti on Cannabis sativa can be found in Jerushalmi et al. (2020). 
TABLE 5 | Diseases reported in C. sativa caused by members of the Fusarium sambucinum species complex.

\begin{tabular}{|c|c|c|c|c|c|}
\hline Species & Initial isolation & Symptoms* & Molecular markers & $\begin{array}{l}\text { Pathogenicity } \\
\text { assays }\end{array}$ & Source \\
\hline \multicolumn{6}{|c|}{ Controlled environments (includes greenhouse, hydroponic, and indoor facilities) } \\
\hline F. graminearum & $\begin{array}{l}\text { Flower buds, } \\
\text { preharvest }\end{array}$ & $\begin{array}{l}\text { Mycelium - prolific whitish-pink, } \\
\text { causes wilt in pathogenicity assay. }\end{array}$ & $\begin{array}{l}\text { EF- } 1 \alpha / E F 1 \text { and EF2 }{ }^{a} \text {; } \\
\text { ITS1-5.8S-ITS2/UN-UP18 S42 and } \\
\text { UN-LO28 S576B }\end{array}$ & Yes, flower buds & Punja and Ni, 2021 \\
\hline \multicolumn{6}{|c|}{ Unspecified or multiple } \\
\hline F. graminearum & $\begin{array}{l}\text { Flowers and } \\
\text { leaves of plants }\end{array}$ & $\begin{array}{l}\text { Foliar and flower blight, circular, } \\
\text { light-brown necrotic lesions, tips of } \\
\text { flowers necrotic, mycelium } \\
\text { apparent }\end{array}$ & $\begin{array}{l}\mathrm{EF}-1 \alpha / \mathrm{EF}-1 \text { and } \mathrm{EF}-2^{\mathrm{a}} \text {; } \\
\text { RPB2/bRPB2-6F and bRPB2-7R } \\
\beta \text {-tubulin/T1 and } \mathrm{T}^{\mathrm{d}} 2^{\mathrm{d}}\end{array}$ & Yes & Thiessen et al., 2020 \\
\hline \multicolumn{6}{|l|}{ Field } \\
\hline F. graminearum & $\begin{array}{l}\text { Flower buds, } \\
\text { preharvest }\end{array}$ & $\begin{array}{l}\text { Bud rot, necrosis, mycelium } \\
\text { apparent }\end{array}$ & $\mathrm{EF}-1 \alpha / \mathrm{EF} 1$ and $\mathrm{EF} 2^{\mathrm{a}}$ & $\begin{array}{l}\text { Yes, flowers of } \\
\text { greenhouse-grown } \\
\text { plants }\end{array}$ & Yulfo-Soto et al., 2021 \\
\hline F. graminearum & $\begin{array}{l}\text { Flower buds, } \\
\text { preharvest }\end{array}$ & $\begin{array}{l}\text { Wilt, co-occurrence with } F \text {. } \\
\text { tricinctum and F. avenaceum }\end{array}$ & $\begin{array}{l}\text { EF- } 1 \alpha / E F 1 \text { and EF2 }{ }^{a} ; \\
\text { ITS1-5.8S-ITS2/UN-UP18 S42 and } \\
\text { UN-LO28 S576B }\end{array}$ & $\begin{array}{l}\text { Yes, rooted } \\
\text { cuttings }\end{array}$ & Punja and Ni, 2021 \\
\hline F. brachygibbosum & $\begin{array}{l}\text { Foliage and } \\
\text { crown }\end{array}$ & $\begin{array}{l}\text { Yellowing of foliage and sunken } \\
\text { lesions in crown. Co-isolated with } \\
\text { F. oxysporum }\end{array}$ & $\begin{array}{l}\text { EF- } 1 \alpha / E F 1 \text { and EF2 }{ }^{a} \text {; } \\
\text { ITS1-5.8S-ITS2/UN-UP18 S42 and } \\
\text { UN-LO28 S576B }\end{array}$ & Not specified & Punja et al., 2019 \\
\hline F. brachygibbosum & $\begin{array}{l}\text { Crown outer } \\
\text { bark, cortical } \\
\text { and vascular } \\
\text { tissues }\end{array}$ & $\begin{array}{l}\text { Yellowing and wilting followed by } \\
\text { total plant collapse in hot weather. } \\
\text { Crown regions-dark and sunken } \\
\text { with internal tissue discoloration. } \\
\text { Root mass reduction. }\end{array}$ & $\begin{array}{l}\text { EF- } 1 \alpha / E F 1 \text { and EF2 }{ }^{\mathrm{a}} \text {; } \\
\text { ITS1-5.8S-ITS2/UN-UP18 S42 and } \\
\text { UN-LO28 S576B }\end{array}$ & $\begin{array}{l}\text { Yes, rooted } \\
\text { cuttings }\end{array}$ & Punja et al., 2018 \\
\hline
\end{tabular}

Molecular regions: EF-1 $\alpha$, Translation elongation factor 1- $\alpha$; ITS1-5.8S-ITS2, Internal transcribed spacer region of ribosomal DNA; RPB2, subunit of RNA polymerase II. a'O'Donnell et al. (1998), 'b Schroeder et al. (2006), ' Matheny (2005), and 'O'Donnell and Cigelnik (1997).

In addition, F. proliferatum also produced beauvericin and moniliformin (O’Donnell et al., 2018).

\section{FUSARIUM IN SEED}

At least one species in each species complex above (except FTSC) has been reported in pre-or post-harvest flower buds of C. sativa. Combined with the fact that Fusarium-associated mycotoxins have been isolated from hemp seed cake and that these pathogens are seed-transmitted in other crops, it is therefore reasonable to assume that $C$. sativa seed have propagules of one or more Fusarium species either in the seed (true seed transmission) or are on the seed surface. In the field, Fusarium graminearum colonized seed of $C$. sativa (Yulfo-Soto et al., 2021). Six Cannabis seed accessions were evaluated as part of a survey of the core collection of the Suceava Genebank, and Fusarium oxysporum was the only pathogen isolated from C. sativa (PlacintăPlacintǎ and Murariu, 2016). Fusarium sp. and F. roseum were isolated from surface-sterilized seeds (Ferri, 1961). McPartland and Hillig recommended that seeds infested by F. oxysporum f. sp. cannabis not be used for human consumption or plant production, but they did not otherwise document presence of the fungus in the seed. Upon germination, species of Fusarium may live as functional endophytes, cause seed rot (Figure 5), or cause damping-off of seedlings. Many species of Fusarium co-exist with their hosts as endophytes and protect the host against pathogens (reviewed in Horinouchi et al., 2011; de Lamo and Takken, 2020), and F. oxysporum has been reported as endophytic in C. sativa (Punja et al., 2019). Other species of Fusarium are reported to infect host seedlings, but foliar disease symptoms are not evident until the host plant enters reproductive stages. Foliar symptoms are caused by toxins produced by the fungus. This is the case with Fusarium virguliforme and sudden death syndrome of soybean (Westphal et al., 2008, updated 2018).

\section{MYCOTOXINS IN CANNABIS}

Mycotoxins are toxic chemicals produced by fungi that have a detrimental effect on plants, animals, or humans. Mycotoxins that are of greatest agronomic importance are produced by many species of Fusarium [fumonisins; trichothecenes (deoxynivalenol, zearalenone; T-2 toxin) (Figure 3A); emerging Fusarium mycotoxins (beauvericin, enniatins, fusaric acid, moniliformin) (Figures 3B,C)] and by other fungi (aflatoxins, ochratoxins, ergot alkaloids, Alternaria toxins, and patulin); limits for the levels of these compounds in the food and feed supply are set by the United States Food and Drug Administration (FDA) and the International Agency of Research on Cancer (see Agriopoulou et al., 2020 for limits set for the United States and Europe). Neither agency, however, currently has limitations for emerging Fusarium mycotoxins (GruberDorninger et al., 2017; Agriopoulou et al., 2020), and the FDA has no established limits for zearalenone, a prominent 


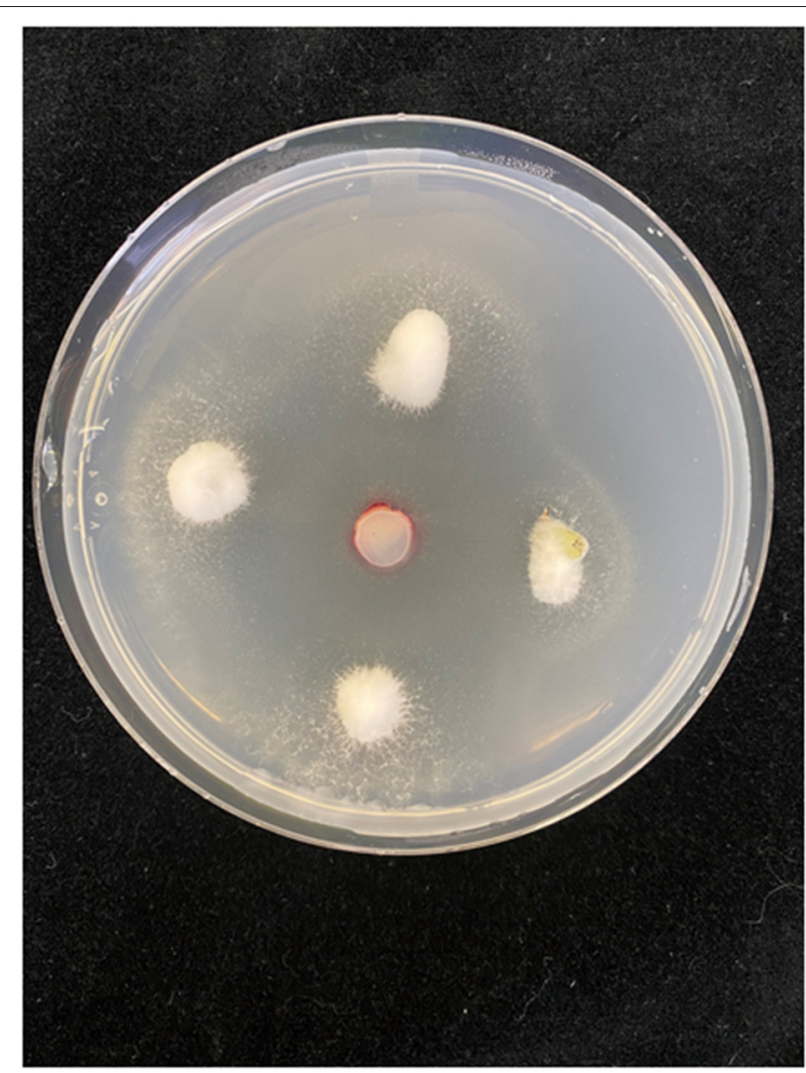

FIGURE 5 | Seed rot assay. Seed were surface sterilized then plated on water agar amended with streptomycin. Four seeds were placed equidistant from an agar plug (control) or from a mycelial plug of a culture of Fusarium sp. isolated from fiber hemp ("Katani"). After 7 days, all seeds in controls germinated, and survived transplanting to soilless medium. In Fusarium treatments, seeds were completely colonized, and only $10 \%$ of seed germinated. Seedlings did not survive after transplanting (photograph by Megan Lee).

trichothecene. Mycotoxins are often virulence factors in plantpathogen interactions (Perincherry et al., 2019), and mycotoxin production has been reported for all Fusarium species associated with $C$. sativa. Although there are few reports of Fusarium mycotoxins in Cannabis and Cannabis-derived products in the refereed literature, it should be emphasized that given the incidence of Fusarium spp. associated with the plant (both preand post-harvest), it is likely that cannabis inflorescences contain these mycotoxins. Four species (F. oxysporum, F. proliferatum, F. sporotrichioides, F. verticillioides) were isolated from dried $C$. sativa flowers from a medical marijuana facility (Punja et al., 2021), and F. lateritium was described as a minor component of the microbiomes of medical dispensary-derived C. sativa samples (McKernan et al., 2016). In addition to potential pathogenesis in immunocompromised individuals, production of mycotoxins in medicinal C. sativa is of concern. The genus produces a diverse array of chemical compounds ranging from cyclic depsipeptides to those derived from farnesyl diphosphate (trichothecenes) (Figure 4A). Species within the same species complex tend to produce similar mycotoxin profiles (O'Donnell et al., 2018), and this is true for Fusarium species that cause disease in Cannabis.
Information on possible synergistic, additive and/or antagonistic effects of mycotoxins in animal and human feedstocks is needed because these interactions may result in unexpected health risks (KríŽová et al., 2021).

In vivo impacts are understudied for most of the emerging mycotoxins, but the effects of these molecules on cellular processes portend effects on the whole animal if these compounds are available in selected combinations and at appropriate concentrations (reviewed in Gruber-Dorninger et al., 2017). Two cyclic depsipeptides, beauvericin and enniatin B, are produced by most species complexes associated with $C$. sativa. The product of the MADS-box transcription factor FoRlm is essential for pathogen virulence and for fusaric acid and beauvericin production in F. oxysporum f. sp. cubense (Ding et al., 2020). In mammalian systems, the enniatins and beauvericin are absorbed and rapidly metabolized most likely by gut microflora (reviewed in KríŽová et al., 2021). Beauvericin and enniatins are ionophores and form ion channels and transport ions $\left(\mathrm{NH}_{4}^{+}\right.$ or $\mathrm{K}^{+}$) across the cell membrane, resulting in disruption of membrane potential which leads to eventual cell death. These compounds initiate apoptosis and may trigger production of reactive oxygen (reviewed in Gruber-Dorninger et al., 2017). Although toxicity of beauvericin was shown in vitro studies, it was not toxic in vivo. Fusaric acid causes cytotoxicity and growth inhibition in vitro and in vivo and results in neurotoxicity and vomiting. Moniliformin disrupts the thiamine pyrophosphatase dependent enzymes of the tricarboxylic acid cycle. Poultry are very sensitive to the compound in all investigated animals, the heart was the primary site of action.

Virulence of F. graminearum is related to the ability to produce deoxynivalenol and its acetyl derivatives (Mielniczuk and Skwaryło-Bednarz, 2020). In mammalian systems, these compounds have genotoxic, cytotoxic, and immunotoxic effects. Zearalenone affects reproduction, immunity, endocrine activities, and inheritance of animals (Zhang et al., 2018a) and has been isolated from human food sources and body fluids (urine and breast milk) (reviewed in Ropejko and Twaruzek, 2021). Trichothecenes can cause both acute and chronic toxicity in humans with symptoms of that include nausea, vomiting, diarrhea, abdominal pain, and fever. At the cellular level, they inhibit protein synthesis, and induce oxidative stress (leading to DNA damage, cell cycle arrest, disrupted cell membrane integrity and function). Trichothecenes can be either immunostimulatory or immunosuppressive, and they induce apoptosis via mitochondria-mediated or -independent pathways (reviewed in Arunachalam and Doohan, 2013).

Fumonisins are produced predominantly by two members of the FSAMSC, F. verticillioides (currently F. fujikuroi) and F. proliferatum. These compounds are well-known hepatotoxic and carcinogenic compounds that inhibit sphingolipid production through selective inhibition of ceramide synthesis (Voss and Riley, 2013). Cannabinoids affect tumor growth through sphingolipid uptake into cancer cells; fumonisin B1 selectively inhibited regulation of tumor growth by cannabinoids (Blázquez et al., 2008). Effects of the fumonisins are systemic and include neurotoxicity, hepatotoxicity, nephrotoxicity, and mammalian cytotoxicity (reviewed in Chen et al., 2021). 
When fungi infect plants, it is rare than only one mycotoxin is produced, and thus, humans and animals are usually exposed to multiple mycotoxins simultaneously. Although in vitro studies are typically limited to one mycotoxin, the co-occurrence of Fusarium mycotoxins in food and feed often results in synergistic toxicity. For example, effects of fumonisins and various trichothecenes were additive or synergistic in $\sim 60 \%$ of in vitro studies, but some relationships were concentration dependent and were antagonistic at select ratios (Alassane-Kpenbi et al., 2017). Interactions between beauvericin and trichothecenes were synergistic, additive, or antagonistic depending on the specific trichothecene and concentration ratios, possibly due to increased uptake facilitated by the ionophore. Relationship between beauvericin and fumonisin was synergistic, but only one study was analyzed. Combinations of enniatins tended to be synergistic or additive, possibly due to their ionophoric activity. Effects of combinations of fusaric acid, trichothecenes, and fumonisin were synergistic or additive (also limited to one study) (Alassane-Kpenbi et al., 2017). Increased knowledge of the emerging Fusarium toxins and their relationships with mycotoxins is crucial to fully define mycotoxicosis in cannabis and hemp due to toxins produced by Fusarium spp.

The refereed literature on mycotoxins in cannabis is sparse and mostly addresses mycotoxins produced by Aspergillus flavus (aflatoxin and ochratoxin A). Aspergillus species have been isolated from C. sativa inflorescences (Punja, 2021a). Growth of $A$. flavus and production of aflatoxin were reduced after in vitro treatment with extracts from $C$. sativa flowers, but not extracts from stems or leaves (Khoury et al., 2021). Processing, whether industrial or home food processing, does not usually eliminate mycotoxins (de Sá et al., 2020). Processes used to concentrate desired chemicals (e.g., cannabinoids and terpenes) can concentrate these compounds. Aflatoxin and ochratoxin A were present in all seven types of Cannabis-derived products sampled (oils containing $\mathrm{CBD}$, gelatin capsules containing $\mathrm{CBD}$, energy drink containing $0.02 \%$ THC-free hemp extract, hemp tea that contained C. sativa, and a butter cookie and a chocolate brownie containing unspecified amounts of THC), but concentration in these products was not higher than in samples of plant material (Wilcox et al., 2020). Chocolate amended with cannabidiol contained aflatoxin and ochratoxin A (ReyesGarcés and Myers, 2021). Hemp flour is hemp seed with oil removed (hemp seed cake) ground into a fine powder. In a survey of grocery store purchased flours, hemp flour contained approximately four times the amount of fumonisin found in wheat flours, but these quantities were lower than FDA advisory for mycotoxins of food (1 ppm); levels of fumonisin were lower in flour stored in paper when compared to that stored in plastic bags (Sacco et al., 2020). Buds and seed from plants with fusarium bud blight (caused by several species of Fusarium spp.) exceeded FDA advisory (Bergstrom et al., 2019). In hemp, CBD is concentrated in the bud, but commercial extractions also include extracts from leaves. In a study on botanical nutraceuticals, Fusarium-associated mycotoxins were quantified in seven out of 10 commercially available CBD-based supplements; one sample contained six mycotoxins (zearalenone, enniatin B, enniatin A, enniatin $\mathrm{A} 1$, and T-2 toxin). Zearalenone ( $60 \%$ of samples) and enniatin B (30\% of samples) were the most prevalent mycotoxins, and $40 \%$ of samples contained more than one mycotoxin (Narváez et al., 2020). Although hemp seed cakes used to formulate animal feed contained Aspergillus-associated toxins (aflatoxin, ochratoxins) and Fusarium-produced toxins (deoxynivalenol, zearalenone, fumonisin $\mathrm{B}$, and $\mathrm{T}-2$, listed in order of concentration), only levels of deoxynivalenol exceeded US animal feed standards (Kasula et al., 2021). These types of studies are urgently needed to assess the potential for mycotoxin accumulation in cannabis and cannabis-derived products.

\section{DISEASE CONTROL}

Given that C. sativa is affected by numerous species of Fusarium that produce mycotoxins and cause crop loss, control of these fungi is pivotal for production of high quality, safe C. sativa and products derived from it. Vegetative propagation used in most production systems geared toward cannabinoid production also results in monocultures that can be decimated by a virulent pathogen. Basic strategies for disease management include exclusion of the pathogen, control of environment, and host resistance. Exclusion remains the most effective step in the production of healthy plants. Use of disease-free transplants [from stock (mother) plants known to be disease-free], seed, greenhouse growing media, and water supplies prevent the introduction of the pathogen (Hansen et al., 2020; Punja, 2021b). In a study investigating the role of Fusarium oxysporum in commercial Cannabis greenhouse production, F. oxysporum was found to spread clonally within production facilities. Additionally, F. oxysporum was detected in spaces dedicated to plant rooting, propagation, and production (Punja, 2021c). These findings underscore the importance of sanitation in commercial production facilities to limit the spread of F. oxysporum and other Fusarium species. Punja and Rodriguez (2018) recovered F. oxysporum and F. solani from hydroponically grown Cannabis plants. They also detected F. oxysporum in recirculating hydroponic nutrient solution, suggesting a potential method of disease spread within hydroponic production facilities, but also highlighting a disease management opportunity. Although there are few conventional pesticide options currently labeled for use on Cannabis, irrigation and recirculated hydroponic water can be treated to reduce water-borne pathogens. One such approach utilizes UV light to sanitize agricultural water. A study investigating the ability of UV light for reducing water-borne plant and human pathogens in surface irrigation water reported 99.9\% inactivation of target organisms following exposure to UV treatment (Jones et al., 2014). In the absence of the full suite of synthetic pesticides available for many other crops, and discussed in more detail below, this type of physical treatment could provide an important tool for Cannabis growers to manage water-borne Fusarium diseases.

Fusarium lichenicola was isolated from two C. sativa production facilities in British Columbia (Punja and Rodriguez, 2018; Punja et al., 2021). Because the pathogen is typically restricted to tropical regions where coco coir is manufactured and has not been reported in British Columbia, the authors 
suggested that the pathogen may have been introduced into the production facilities via the coco coir medium used for plant propagation (Punja et al., 2021). Fusarium species were also recovered from rooted cuttings obtained from commercial propagation facilities (Punja and Rodriguez, 2018). Most species of Fusarium are soilborne and can survive in the soil for years without a host. Samples from greenhouses using soil as a growth substrate had higher numbers of fungi than those in hydroponic systems, but F. oxysporum was also isolated from plants grown hydroponically, as previously discussed (Punja, 2018). These sources of Fusarium inoculum highlight the importance of pathogen-free growing media and disease-free plant material. For field production, avoiding the movement of soil between fields limits the introduction of pathogens into new production areas (Hansen et al., 2020). Many diseases caused by Fusarium may be partially controlled by cultural practices that modify the environment. Spacing plants and orienting fields to maximize air flow and rapid drying of foliage, as well as management of weeds avoids humid microclimates that promote fungal growth (Hansen et al., 2020). Some weeds may also harbor Fusarium species that are pathogenic on Cannabis. Punja and Rodriguez (2018) isolated Fusarium species that shared $99-100 \%$ ITS and EF-1 $\alpha$ sequence homology with isolates that cause disease in nonCannabis hosts, including cumin and tomato, indicating that at least some of the Fusarium species impacting Cannabis may not be host-specific or may have originated from other host plants. Cultivars with large dense inflorescences retain moisture and have a higher incidence of bud rot, therefore selecting varieties with smaller inflorescences can prevent establishment of these pathogens (Punja, 2021b).

Sanitation is important for pathogen exclusion as well as managing Fusarium disease once it becomes established. Removal of infected plants or diseased cuttings from production facilities can reduce spread of the pathogen (Hansen et al., 2020; Punja, 2021b). Strict hygiene measures (e.g., sterilization of cutting tools, restricted movement of workers and equipment in facilities) can also reduce pathogen dissemination. Rotation is often an effective method for disease control; however, unlike FoxC, host ranges for most Fusarium species that cause disease in C. sativa are not known but are likely to be wide. Some isolates of F. oxysporum and F. solani have a wide host range. Thus, rotation in Cannabis production may or may not reduce disease pressure. Unless FoxC was introduced via seed or cuttings, it is unlikely that isolates of $F$. oxysporum in North America are FoxC but rather may be generalists. McGehee and Raudales (2021) firmly established that $F$. oxysporum isolated in a Connecticut marijuana production facility was not closely related to FoxC.

There is little research on host resistance to diseases caused by species of Fusarium. For FoxC, cultivars that are less susceptible to the disease have replaced those planted in the 1950s and 60 s, and in variety testing, disease incidence and severity were less for these varieties than varieties from Pakistan, Turkey, Thailand, India, Nepal, South Africa, Czechoslovakia (now the Czech Republic or Slovakia), Poland, or Iran (McCain and Noviello, 1985). These results were confirmed in 1990 field and container studies in which cultivars from Iran and India were very sensitive to the disease at low inoculum levels $\left(1 \mathrm{~g} / \mathrm{m}^{2}\right)$, and losses due to FoxC in two Italian cultivars (Super Fibra and Carmagnola Selezionata) were low even at elevated levels of inoculum (Noviello et al., 1990). In an in vitro assay utilizing stem colonization as a measure of resistance, there were no significant differences in colonization scores for the five cannabis strains assessed (Punja, 2021c). To our knowledge, there have been no additional reports of Fusarium-resistant cultivars in C. sativa as there are in other host plants affected by F. oxysporum.

Cannabis sativa is a high value crop, and there is an urgent need for chemical and biological control strategies. For fiber hemp, seed treatment with conventional fungicides reduced incidence of damping-off caused by F. solani (Mishra, 1987). Pesticide residues are particularly important in C. sativa grown for medical purposes, but the low number of products approved for disease control, the continued use of control methods that evolved when the plant was illegal, and the lack of scrutiny normally provided by the food and drug approval process (Seltenrich, 2019; Pinkhasova et al., 2021) have resulted in illegal pesticide residues being commonly found in Cannabis products (Narváez et al., 2020; López-Ruiz et al., 2021). Health Canada maintains a nationwide program that couples unannounced inspections and targeted testing to monitor pesticide use and reduce the potential risk to public health (Health Canada, 2019), whereas in the USA, residues are regulated on a state-by-state basis. In US states where medical cannabis is legal, strictest EPA tolerances for up to 400 active ingredients were imposed in six states, whereas testing was voluntary in three states (Pinkhasova et al., 2021).

Beginning in December 2019, hemp was added to labels of 49 pesticide products by the US EPA (https:// 19january2021snapshot.epa.gov/pesticide-registration/

pesticide-products-registered-use-hemp_html). Forty-eight of these products are biopesticides, and one is a conventional pesticide. Only $40 \%$ of these pesticides list fungicide activity in their labels, but $60 \%$ of fungicides specifically mention Fusarium control on the labels. Microbial pesticides represent $34 \%$ of the biopesticides. In addition, 14 out of the 23 fungicides registered for C. sativa disease control in Canada are microbial biopesticides. Efficacy of approved fungicides against Fusarium in C. sativa has rarely been reported in the refereed literature. Use of fungicides approved for control of Fusarium species in other crops may provide control, but growers should be cautious as some of these products can be phytotoxic on $C$. sativa (Akinrinlola et al., 2021). Treatment of cuttings from the cannabis strain, "White Rhino" with Lalstop G46 (Gliocladium catenulatum J1446), RootShield Plus (Trichoderma harzianum Rifai strain T-22 and $T$. virens G-41), Asperello T34 ( $T$. asperellum T34), and Stargus (Bacillus amyloliquefaciens F727) reduced severity of disease caused by $F$. oxysporum by 30 $56.3 \%$ of the untreated control, whereas disease severity in cuttings treated with Rhapsody (Bacillus subtilis QST 713) were not different than untreated control (Scott, 2017). Double Nickel (Bacillus amyloliquefaciens strain D747) and Quadris (azoxystrobin) were both ineffective at reducing incidence of Fusarium wilt caused by $F$. oxysporum in a field trial in North Carolina (Thiessen et al., 2020). Growth promoting organisms such as plant growth promoting rhizobacteria 
(PGPR) do not require approval for use in plant production if disease control claims are not made, but many have been shown to increase disease resistance in other systems. In $C$. sativa, treatment with PGPR reduced incidence of diseases caused by pathogenic fungi. Five putative defense genes were "strongly and sustainably induced locally" in C. sativa at the infection sites of Botrytis cinerea (Balthazar et al., 2020). Many growers add mycorrhizal inoculum to C. sativa production systems to increase plant quality, but there are no reports on using these microorganisms alone or in combination with other microbial pesticides for control of disease. Additional studies are needed to determine if these types of treatments are effective against diseases caused by Fusarium.

Most of the biochemical biopesticides registered on hemp are extracts from the neem tree (neem oil, cold pressed neem oil, and azadirachtin), but there are few reports in the refereed literature on efficacy of these products in cannabis and none for control of Fusarium. Regalia, an extract of Reynoutria sachalinensis, is specifically labeled for use against F. oxysporum f. sp. cannabis, fusarium wilt and fusarium damping off in C. sativa. When C. sativa strain, "Hashplant," was treated with different biofungicides, disease severity in treatments with Regalia was not different from no-pathogen control, whereas severity in microbial treatments (RootShield, Prestop 4B (G. catenulatum J1446), Rhapsody, RootShield Plus, and Stargus) and in treatments with Karanja oil were not significantly different from the positive pathogen controls (Lung et al., 2019). Thyme oil and a combination of ethaneperoxoic acid and hydrogen peroxide are listed as soil treatments for control of Fusarium.

\section{SUMMARY}

Throughout this review, the statement has been repeatedly made that there are few or no reports in the refereed literature on various aspects of Fusarium epidemiology and management. Together, the economic importance of products derived from $C$. sativa and the potential of species of Fusarium to cause significant economic losses reductions in plant productivity and presence of mycotoxin residues make a compelling case that additional studies are urgently needed. New disease control strategies, particularly those developing integrated pest and pathogen management plans, are a pressing need. Disease resistant cultivars are crucial in development of reliable crop production systems. Transmission of Fusarium and other pathogens in seed of cannabis has been demonstrated in earlier studies, but few studies on seed borne transmission or on treatment in modern varieties have been conducted. In the USA and Canada, fungicides currently available for use on C. sativa rely on few active ingredients, many of which are of limited or unknown value for protection against diseases caused by Fusarium sp. Development and implementation of low toxicity products are especially necessary since smoke from this plant is often inhaled, thereby exposing highly absorptive tissues in the lungs to residues. In addition, lack of high throughput screening methods make testing for resistance to pathogens and pesticide efficacy time- and labor-intensive (Punja, 2021b). Thus, fewer pathogenicity studies than pathogen descriptions may result. Although these studies for all these deficits are urgently needed by the burgeoning cannabis industry, there is very limited funding to support these research needs.

Furthermore, the issues identified in the preceding paragraph are true for other pathogens of C. sativa. However, there are problems unique to the study of Fusarium in C. sativa. The controversy over the taxonomic placement of species in the FSSC is not merely an academic disagreement; it leads to further confusion for practitioners (e.g., plant pathologists, medical mycologists, quarantine officials, regulatory agencies) and for researchers (Geiser et al., 2021). In addition, immunocompromised patients who rely on cannabis as a medicinal can unwittingly subject themselves to fungi that have the potential to colonize human tissue and produce toxic compounds (McKernan et al., 2016; Punja, 2021a). Methodologies for mycotoxin extraction and analysis have been developed, new methods are continuing to be described, and analysis by government agencies and commercial companies is available. Mycotoxin analysis should be included in combination with other chemical testing in research studies when Fusarium or Aspergillus infection is confirmed or suspected. Finally, few of the pathogens described in this review are unique to cannabis cultivation so lack of control on C. sativa may provide inoculum for other established crops (e.g., Fusarium head blight of grains), and isolation of these pathogens from controlled environments leads to the prospect that cannabis cultivation could provide inoculum earlier in the season than currently occurs. Additionally, a range of crops grown in close proximity to cannabis and hemp are known to provide inoculum of Fusarium species that can affect these crops. Therefore, careful consideration of planting schemes that avoid including hosts of Fusarium species close to cannabis and hemp should be made.

\section{AUTHOR CONTRIBUTIONS}

$\mathrm{KDG}, \mathrm{ZH}$, and $\mathrm{BHO}$ reviewed the literature and assembled summary tables. KDG wrote the first drafts. All authors edited the final manuscript.

\section{FUNDING}

This work was supported by the USDA National Institute of Food and Agriculture, Hatch Multistate Project Number TEN00573.

\section{ACKNOWLEDGMENTS}

The authors gratefully acknowledge the contribution of REACH Scholars in development of the original materials used in this manuscript. Rowan Hatagan and Joel Villalobos isolated the Fusarium sp. used in the seed rot assays. Megan Lee performed the seed rot assay and provided the photograph of the assays. Megan Lee, Kelly Jones, and Rowan Hatagan provided routine culture management. 


\section{REFERENCES}

Adhikary, D., Kulkarni, M., El-Mezawy, A., Mobini, S., Elhiti, M., Gjuric, R., et al. (2021). Medical cannabis and industrial hemp tissue culture: present status and future potential. Front. Plant Sci. 12:627240. doi: 10.3389/fpls.2021.627240

Agriopoulou, S., Stamatelopoulou, E., and Varzakas, T. (2020). Occurrence, importance, and mycotoxin control strategies: prevention and detoxification in foods. Foods 9:137. doi: 10.3390/foods9020137

Agrios, G. N. (ed.). (2005). Plant Pathology, 5th Edn. Burlington, MA: Elsevier Academic Press.

Akinrinlola, R., Hansen, Z., Wang, T., Gwinn, K. D., and Fei, T. (2021). Fungicide efficacy against hemp powdery mildew in the greenhouse (Abstr.). Phytopathology (in press). Presented at Plant Health 2021 - Annual Meeting of the American Phytopathological Society (Virtual).

Alassane-Kpenbi, I., Schatzmayr, G., Taranu, I., Marin, D., Puel, O., and Oswald, I. P. (2017). Mycotoxins co-contamination: methodological aspects and biological relevance of combined toxicity studies. Crit. Rev. Food Sci. Nutr. 57, 3489-3507. doi: 10.1080/10408398.2016.1140632

Andre, C. M., Hausman, J.-F., and Guerriero, G. (2016). Cannabis sativa: the plant of the thousand and one molecules. Front. Plant Sci. 7:19. doi: $10.3389 /$ fpls.2016.00019

Arunachalam, C., and Doohan, F. M. (2013). Trichothecene toxicity in eukaryotes: cellular and molecular mechanisms in plants and animals. Toxicol. Lett. 217, 149-158. doi: 10.1016/j.toxlet.2012.12.003

Balthazar, C., Cantin, G., Novinscak, A., Joly, D. L., and Fikion, M. (2020). Expression of putative defense responses in Cannabis primed by Pseudomonas and/or Bacillus strains and infected by Botrytis cinerea. Front. Plant Sci. 11:57211225. doi: 10.3389/fpls.2020.572112

Barboza, N., Akinrinlola, R., Gwinn, K. D., Kelly, H., and Hansen, Z. (2021). "Fusarium species associated with hemp in Tennessee," in Virtual Science of Hemp Conference: Student Poster. Available online at: http://scienceofhemp.ca. uky.edu/proceedings

Bergstrom, G., Starr, J., Myers, K., and Cummings, J. (2019). "An early view of diseases affecting hemp in New York," in Science of Hemp: Production and Management (University of Kentucky College of Agriculture Food and Environment SR-112). Available online at: https://plantpathology.ca.uky.edu/ files/sr112.pdf (accessed October 11, 2021).

Blázquez, C., Carracedo, A., Salazar, M., Lorente, M., Egia, A., González-Feria, L., et al. (2008). Down-regulation of tissue inhibitor of metalloproteinases1 in gliomas: a new marker of cannabinoid antitumoral activity? Neuropharmacology 54, 235-243. doi: 10.1016/j.neuropharm.2007.06.021

Bruehl, G. W. (1987). Soilborne Plant Pathogens. New York, NY: Macmillan Pub. Co.

Carbone, I., and Kohn, L. M. (1999). A method for designing primer sets for speciation studies in filamentous ascomycetes. Mycologia 91, 553-556. doi: $10.2307 / 3761358$

Chawla, S., Geyer, E., Dhakal, R., Ren, S., and Mersha, Z. (2021). "Fusarium head and bud blight detected on hemp varieties in Virginia," in Virtual Science of Hemp Conference: Pest Management. Available online at: http://scienceofhemp. ca.uky.edu/proceedings

Chen, J., Wei, Z., Wang, Y., Long, M., Wu, W., and Kuca, K. (2021). Fumonisin B1: mechanisms of toxicity and biological detoxification progress in animals. Food Chem. Toxicol. 149:111977. doi: 10.1016/j.fct.2021.111977

Cormier, C., Blanchet, V., and Joly, D. L. (2019). "Survey of diseases and pests affecting hemp in New Brunswick, Canada," in Science of Hemp: Production and Management (University of Kentucky College of Agriculture Food and Environment SR-112). Available online at: https://plantpathology.ca.uky.edu/ files/sr112.pdf (accessed October 11, 2021).

Crous, P. W., Lombard, L., Sandoval-Denis, M., Seifert, K. A., Schroers, H.-J., Chaverri, P., et al. (2021). Fusarium: more than a node or a foot-shaped basal cell. Stud. Mycol. 98:10116.

de Lamo, F. J., and Takken, F. L. W. (2020). Biocontrol by Fusarium oxysporum using endophyte-mediated resistance. Front. Plant Sci. 11:37. doi: $10.3389 /$ fpls.2020.00037

de Sá, S. V. M., Monteiro, C., Fernandes, J. O., Pinto, E., Faria, M. A., and Cunha, S. C. (2020). Emerging mycotoxins in infant and children foods: a review. Crit. Rev. Food Sci. Nutr. doi: 10.1080/10408398.2021. 1967282
Ding, Z., Xu, T., Zhu, W., Li, L., and Fu, Q. (2020). A MADS-box transcription factor FoRlm1 regulates aerial hyphal growth, oxidative stress, cell wall biosynthesis and virulence in Fusarium oxysporum f. sp. cubense. Fungal Biol. 124, 183-193. doi: 10.1016/j.funbio.2020.02.001

FAOSTAT (2019). Food and Agriculture Data. Available online at: https://www.fao. org/faostat/en/\#home (accessed November 3, 2021).

Ferri, F. (1961). Microflora dei semi di canapa. Progresso Agricolo (Bologna) 7, 349-356.

Gardes, M., and Bruns, T. D. (1993). ITS primers with enhanced specificity for Basidiomycetes: application to the identification of mycorrhizae and rusts. Mol. Ecol. 2, 113-118. doi: 10.1111/j.1365-294X.1993.tb00005.x

Geiser, D. M., Al-Hatmi, A. M. S., Aoki, T., Arie, T., Balmas, V., Barnes, I., et al. (2021). Phylogenomic analysis of a $55.1 \mathrm{~kb} 19$-gene dataset resolves a monophyletic Fusarium that includes the Fusarium solani species complex. Phytopathology 111, 1064-1079. doi: 10.1094/PHYTO-08-20-0330-LE

Gruber-Dorninger, C., Novak, B., Nagl, V., and Berthiller, F. (2017). Emerging mycotoxins: beyond traditionally determined food contaminants. J. Agric. Food Chem. 65, 7052-7070. doi: 10.1021/acs.jafc.6b03413

Hansen, Z., Bernard, E. C., Grant, J. F., Gwinn, K. D., Hale, F., Kelly, H., et al. (2020). Hemp Disease and Pest Management. University of Tennessee Extension Publication W916. Available online at: https://hemp.tennessee.edu/wpcontent/uploads/sites/183/2020/12/Hemp_Disease_and_Pest_Management_ W916.pdf (accessed October 11, 2021).

Hasse, J. (2020). Canada Cannabis Sales Doubled in Hitting \$2.6 Billion: Here's What's Next. Available online at: https://www.forbes.com/sites/javierhasse/ 2021/04/14/canada-cannabis-sales-doubled-in-2020-hitting-26b-hereswhats-next/?sh=690d710f494f (accessed October 30, 2021).

Health Canada (2019). Mandatory Cannabis Testing for Pesticide Active Ingredients - Requirements. Available online at: https://www.canada.ca/content/dam/phacaspc/documents/services/publications/drugs-health-products/cannabistesting-pesticide-list-limits/Mandatory-Cannabis-Testing-Requirements.pdf (accessed October 11, 2021).

Hildebrand, D. C., and McCain, A. H. (1978). The use of various substrates for large-scale production of Fusarium oxysporum f. sp. cannabis inoculum. Phytopathology 68, 1099-1101.

Horinouchi, H., Watanabe, H., Taguchi, Y., Muslim, A., and Hyakumachi, M. (2011). Biological control of Fusarium wilt of tomato with Fusarium equiseti GF191 in both rock wool and soil systems. Bio Control 56, 915-923. doi: 10.1007/s10526-011-9369-3

Huber, D. M., and Thompson, I. A. (2009). "Nitrogen and plant disease," in Mineral Nutrition and Plant Disease, eds L. E. Datnoff, W. H. Elmer, and D. M. Huber (St. Paul, MN: The American Phytopathological Society), 31-44.

Jerushalmi, S., Maymon, M., Dombrovsky, A., and Freeman, S. (2020). Fungal pathogens affecting the production and quality of medical cannabis in Israel. Plants 7:882. doi: 10.3390/plants9070882

Johnson, N. (2019). American weed: a history of Cannabis cultivation in the United States". EchoGéo 48:17650. doi: 10.4000/echogeo.17650

Jones, L. A., Worobo, R. W., and Smart, C. D. (2014). UV light inactivation of human and plant pathogens in unfiltered surface irrigation water. Appl. Environ. Microbiol. 80, 849-854. doi: 10.1128/AEM.02964-13

Kasula, R., Solis, F., Shaffer, B., Connett, F., Barrett, C., Cocker, R., et al. (2021). Characterization of the nutritional and safety properties of hemp seed cake as animal feed ingredient. Int. J. Livest. Prod. 12, 53-63. doi: 10.5897/IJLP2020.0750

Khoury, A. A., Sleiman, R., Atoui, A., Hindieh, P., Maroun, P. G., and Bailly, J.D. (2021). Antifungal and anti-aflatoxigenic properties of organs of Cannabis sativa L: relation to phenolic content and antioxidant capacities. Arch. Microbiol. 203, 4485-4492. doi: 10.1007/s00203-021-02444-x

KríŽová, L., Dadáková, K., Dvoráčková, M., and Kašparovský, T. (2021). Feedborne mycotoxins beauvericin and enniatins and livestock animals. Toxins 13:32. doi: $10.3390 /$ toxins 13010032

Leslie, J. F., and Summerell, B. A. (2006). The Fusarium Laboratory Manual. Ames, IA: Blackwell Publishing.

Lombard, L., Sandoval-Denis, S. C., and Crous, P. W. (2019). Epitypification of Fusarium oxysporum - clearing the taxonomic chaos. Persoonia 43, 1-47. doi: $10.3767 /$ persoonia.2019.43.01

López-Ruiz, R., Marín-Sáez, J., Frenich, A. G., and Romero-González, R. (2021). Recent applications of chromatography for analysis of contaminants 
in cannabis products: a review. Pest Manag. Sci. doi: 10.1002/ps. 6599

Lung, S. M., Betz, E. C., Roberts, A. J., and Punja, Z. K. (2019). Infection of Cannabis sativa Cuttings by Fusarium oxysporum and Fusarium proliferatum and Investigation Into Potential Biofungicide Control. Canadian Phytopathological Society - BC Regional Meeting 2019. Available online at: https://www. researchgate.net/publication/336889937_Infection_of_Cannabis_sativa_ cuttings_by_Fusarium_oxysporum_and_Fusarium_proliferatum_and_ investigation_into_potential_biofungicide_control (accessed December 10, 2021).

Mark, T., Shepherd, J., Olson, D., Snell, W., Proper, S., and Thornsbury, S. (2020). Economic Viability of Industrial Hemp in the United States: A Review of State Pilot Programs. EIB-217, U.S. Department of Agriculture, Economic Research Service. Available online at: https://www.ers.usda.gov/publications/ pub-details/?pubid=95929 (accessed November 5, 2021).

Matheny, P. B. (2005). Improving phylogenetic inference of mushrooms with RPB1 and RPB2 nucleotide sequences (Inocybe; Agaricales). Mol. Phylogenet. Evol. 35, 1-20. doi: 10.1016/j.ympev.2004.11.014

McCain, A. H., and Noviello, C. (1985). "Biological control of Cannabis sativa," in Proceedings of the VI International Symposium on Biological Control of Weeds (Vancouver, BC). ed E. S. Delfosse, 635-642.

McGehee, C. S., and Raudales, R. E. (2021). Pathogenicity and mefenoxam sensitivity of Pythium, Globisporangium, and Fusarium isolates from coconut coir and rockwool in marijuana (Cannabis sativa L.) production. Front. Agron. 3:706138. doi: 10.3389/fagro.2021.706138

McKernan, K., Spangler, J., Zhang, L., Tadigotla, V., Helbert, Y., Foss, T., et al. (2016). Cannabis microbiome sequencing reveals several mycotoxic fungi native to dispensary grade Cannabis flowers. F1000Research 4:1422 doi: 10.12688/f1000research.7507.2

McPartland, J. M. (2018). Cannabis systematics at the levels of family, genus, and species. Cannabis Cannabinoid Res. 3, 203-212. doi: 10.1089/can.2018.0039

McPartland, J. M., and Hillig, K. W. (2004). Cannabis clinic fusarium wilt. J. Ind. Hemp 9, 67-77. doi: 10.1300/J237v09n02_07

Mielniczuk, E., and Skwaryło-Bednarz, B. (2020). Fusarium head blight, mycotoxins, and strategies for their reduction. Agronomy 10:509. doi: 10.3390/agronomy10040509

Mishra, D. (1987). Damping off of Cannabis sativa caused by Fusarium solani and its control by seed treatment. Indian J. Phytopathol. 17, 100-102.

Narváez, A., Rodríguez-Carrasco, Y., Castaldo, L., Izzo, L., and Ritieni, A. (2020). Ultra-high-performance liquid chromatography coupled with quadrupole orbitrap high-resolution mass spectrometry for multi-residue analysis of mycotoxins and pesticides in botanical nutraceuticals. Toxins 12:114. doi: 10.3390/toxins12020114

Noviello, C., McCain, A. H., Aloj, B., Scalcione, M., and Marziano, F. (1990). Lotta biologica contro Cannabis sativa medlante l'impiego di Fusarium oxysporum $\mathrm{f}$. sp. cannabis. Annali delta Facolta di Scienze Agrarie della Universita degli Studi di Napoli. Portici 24, 33-44.

Noviello, C., and Snyder, W. C. (1962). Fusarium wilt of hemp. Phytopathology 52, 1316-1317.

O’Donnell, K., Al-Hatmi, A. M. S., Aoki, T., Brankovics, B., Cano-Lira, J. F., Coleman, J. J., et al. (2020). No to Neocosmospora: phylogenomic and practical reasons for continued inclusion of the Fusarium solani species complex in the genus Fusarium. mSphere 5, e00810-e00820. doi: 10.1128/mSphere. 00810-20

O’Donnell, K., and Cigelnik, E. (1997). Two divergent intragenomic rDNA ITS2 types within a monophyletic lineage of the fungus Fusarium are nonorthologous. Mol. Phylogenet. Evol. 7, 103-116. doi: 10.1006/mpev.1996.0376

O’Donnell, K., Gueidan, C., Sink, S., Johnston, P. R., Crous, P. W., Glenn, A., et al. (2009). A two-locus DNA sequence database for typing plant and human pathogens within the Fusarium oxysporum species complex. Fungal Genet. Biol. 46:936-948. doi: 10.1016/j.fgb.2009.08.006

O’Donnell, K., Kistler, H. C., and Cigelnik, E., Ploetz, R. C. (1998). Multiple evolutionary origins of the fungus causing Panama disease of banana: concordant evidence from nuclear and mitochondrial gene genealogies. Proc. Natl. Acad. Sci. U.S.A. 95, 2044-2049. doi: 10.1073/pnas.95.5.2044

O’Donnell, K., McCormick, S. P., Busman, M., Proctor, R. H., Ward, T. J., Doehring, G., et al. (2018). Marasas et al. 1984 "Toxigenic Fusarium species: identity and mycotoxicology" revisited. Mycologia 110, 1058-1080. doi: 10.1080/00275514.2018.1519773

O’Donnell, K., Sutton, D. A., Fothergill, A., McCarthy, D., Rinaldi, M. G., Brandt, M. E., et al. (2008). Molecular phylogenetic diversity, multilocus haplotype nomenclature, and in vitro antifungal resistance within the Fusarium solani species complex. J. Clin. Microbiol. 46, 2477-2490. doi: 10.1128/JCM.02371-07

Perincherry, L., Lalak-Kańczugowska, J., and Stepień, Ł. (2019). Fusariumproduced mycotoxins in plant-pathogen interactions. Toxins 11:664. doi: 10.3390/toxins11110664

Pinkhasova, D. V., Jameson, L. E., Conrow, K. D., Simeone, M. P., Davis, A. P., Wiegers, T. C., et al. (2021). Regulatory status of pesticide residues in cannabis: implications to medical use in neurological diseases. Curr. Res. Toxicol. 2, 140-148. doi: 10.1016/j.crtox.2021.02.007

Placintǎ D. D., and Murariu, D. (2016). Fungus evaluation from seeds germplasm before medium and long term storage. Cercetări Agronomice Moldova 49, 71-82. doi: 10.1515/cerce-2016-0027

Punja, Z. K. (2018). Flower and foliage-infecting pathogens of marijuana (Cannabis sativa L., marijuana). Can. J. Plant Pathol. 40, 514-527. doi: 10.1080/07060661.2018.1535467

Punja, Z. K. (2021a). The diverse mycoflora present on dried cannabis (Cannabis sativa L., marijuana) inflorescences in commercial production. Can. J. Plant Pathol. 43, 88-100. doi: 10.1080/07060661.2020.1758959

Punja, Z. K. (2021b). Emerging diseases of Cannabis sativa and sustainable management. Pest Manag. Sci. 77, 3857-3870. doi: 10.1002/ps.6307

Punja, Z. K. (2021c). Epidemiology of Fusarium oxysporum causing root and crown rot of cannabis (Cannabis sativa L., marijuana) plants in commercial greenhouse production. Can. J. Plant Pathol. 43, 216-235. doi: 10.1080/07060661.2020.1788165

Punja, Z. K. (2021d). First report of Fusarium proliferatum causing crown and stem rot, pith necrosis in cannabis (Cannabis sativa L., marijuana) plants. Can. J. Plant Pathol. 43, 236-255. doi: 10.1080/07060661.2020.1793222

Punja, Z. K., Collyer, D., Scott, C., Lung, S., Holmes, J., and Sutton, D. (2019). Pathogens and molds affecting production and quality of Cannabis sativa L. Front. Plant Sci. 10:1120. doi: 10.3389/fpls.2019.01120

Punja, Z. K., and Ni, L. (2021). The bud rot pathogens infecting cannabis (Cannabis sativa L., marijuana) inflorescences: symptomology, species identification, pathogenicity, and biological control. Can. J. Plant Pathol. doi: 10.1080/07060661.2021.1936650

Punja, Z. K., Ni, L., and Roberts, A. (2021). The Fusarium solani species complex infecting cannabis (Cannabis sativa L., marijuana) plants and a first report of Fusarium (Cylindrocarpon) lichenicola causing root and crown rot. Can. J. Plant Pathol. 43, 567-581. doi: 10.1080/07060661.2020.1866672

Punja, Z. K., and Rodriguez, G. (2018). Fusarium and Pythium species infecting roots of hydroponically grown marijuana (Cannabis sativa L.) plants. Can. J. Plant Pathol. 40, 498-513. doi: 10.1080/07060661.2018.15 35466

Punja, Z. K., Scott, C., and Chen, S. (2018). Root and crown rot pathogens causing wilt symptoms on field-grown marijuana (Cannabis sativa L.) plants. Can. J. Plant Pathol. 40, 528-541. doi: 10.1080/07060661.2018.1535470

Pusiak, R. J. P., Cox, C., Cory, S., and Harris, C. S. (2021). Growing pains: an overview of cannabis quality control and quality assurance in Canada. Int. J. Drug Policy 93:103111. doi: 10.1016/j.drugpo.2021.103111

Reyes-Garcés, N., and Myers, C. (2021). Analysis of the California list of pesticides, mycotoxins, and cannabinoids in chocolate using liquid chromatography and low-pressure gas chromatography-based platforms. J. Sep. Sci. 44, 2564-2576. doi: $10.1002 /$ jssc. 202001265

Ricciardil, M. M., Villanueva, R., Gauthier, N., and Pearce, R. (2021). “Observations of insect and disease pests on field grown hemp in Kentucky," in Virtual Science of Hemp Conference: Poster Presentations. Available online at: http:// scienceofhemp.ca.uky.edu/proceedings

Ropejko, K., and Twaruzek, M. (2021). Zearalenone and its metabolites-general overview, occurrence, and toxicity. Toxins 13:35. doi: 10.3390/toxins13010035

Sacco, C., Donatoa, R., Zanella, B., Pinia, G., Pettinia, L., Marino, M. F., et al. (2020). Mycotoxins and flours: effect of type of crop, organic production, packaging type on the recovery of fungal genus and mycotoxins. Int. J. Food Microbiol. 334:108808. doi: 10.1016/j.ijfoodmicro.2020.108808

Schroeder, K. L., Okubara, P. A., Tambong, J. T., Lévesque, C. A., and Paulitz, T. C. (2006). Identification and quantification of pathogenic Pythium spp. 
from soils in eastern Washington using real-time polymerase chain reaction. Phytopathology 96, 637-647. doi: 10.1094/PHYTO-96-0637

Scott, C. A. (2017). Disease Management Approaches for Cannabis sativa L. M. S. Thesis Simon Fraser University, 132p.

Seltenrich, N. (2019). Into the weeds: regulating pesticides in cannabis. Environ. Health Perspect. 127:042001. doi: 10.1289/EHP5265

Short, D. P. G., O’Donnell, K., Thrane, U., Nielsen, K. F., Zhang, N., Juba, J. H., et al. (2013). Phylogenetic relationships among members of the Fusarium solani species complex in human infections and the descriptions of $F$. keratoplasticum sp. nov. and F. petrophilum stat. nov. Fungal Genet. Biol. 53, 59-70. doi: 10.1016/j.fgb.2013.01.004

Smith, H., Dixon, E., Yulfo-Soto, G., and Gauthier, N. (2021). "Identification and characterization of Fusarium spp. affecting Kentucky Hemp," in Virtual Science of Hemp Conference: Student Presentations. Available online at: http:// scienceofhemp.ca.uky.edu/proceedings

Sorrentino, R., Pergamo, R., Battaglia, V., Raimo, F., Cermola, M., and Lahoz, E. (2019). Characterization and pathogenicity of Fusarium solani causing foot rot on hemp (Cannabis sativa L.) in southern Italy. J. Plant Dis. Protect. 126, 585-591. doi: 10.1007/s41348-019-00265-1

Summerell, B. A. (2019). Resolving Fusarium: current status of the genus. Annu. Rev. Phytopathol. 57, 323-339. doi: 10.1146/annurev-phyto-082718-100204

Summerell, B. A., Salleh, B., and Leslie, J. F. (2003). A utilitarian approach to Fusarium identification. Plant Dis. 87, 117-128.

Thiessen, L. D., Schappe, T., Cochran, S., Hicks, K., and Post, A. R. (2020). Surveying for potential diseases and abiotic disorders of industrial hemp (Cannabis sativa) production. Plant Health Prog. 21, 321-332. doi: 10.1094/PHP-03-20-0017-RS

Tiourebaev, K. S., Semenchenko, G. V., Dolgovskaya, M., McCarthy, M. K., Anderson, T. W., Carsten, L. D., et al. (2001). Biological control of infestations of ditchweed (Cannabis sativa) with Fusarium oxysporum f. sp. cannabis in Kazakhstan. Biocontr. Sci. Technol. 11, 535-540. doi: 10.1080/09583150120067562

Voss, K. A., and Riley, R. T. (2013). Fumonisin Toxicity and Mechanism of Sction: Overview and Current Perspectives. Food Safety Commission, Cabinet Office, Government of Japan. doi: 10.14252/foodsafetyfscj.2013006

Westphal, A., Abney, T. S., Xing, L. J., and Shaner, G. E. (2008). Sudden Death Syndrome of Soybean. The Plant Health Instructor. Available online at: https://www.apsnet.org/edcenter/disandpath/fungalasco/pdlessons/ Pages/SuddenDeath.aspx

White, T. J., Burns, T., Lee, S., and Taylor, J. (1990). “Amplification and direct sequencing of fungal ribosomal RNA genes for phylogenetics," in PCR Protocols: A Guide to Methods and Applications, eds M. A. Innis, D. H. Gelfand, J. J. Sninsky, and T. J. White (San Diego, CA: Academic Press, Inc), 315-322.

Wilcox, J., Pazdanska, M., Milligan, C., Chan, D., MacDonald, S. J., and Donnelly, C. (2020). Analysis of aflatoxins and ochratoxin A in Cannabis and Cannabis products by LC-fluorescence detection using cleanup with either multiantibody immunoaffinity columns or an automated system with in-line reusable immunoaffinity cartridges. J. AOAC Intern. 103, 494-503. doi: 10.5740/jaoacint.19-0176

Yakowicz, W. (2021). U.S. Cannabis Sales Hit Record \$17.5 Billion as Americans Consume More Marijuana Than Ever Before. Available online at: https://www. forbes.com/sites/willyakowicz/2021/03/03/us-cannabis-sales-hit-record175-billion-as-americans-consume-more-marijuana-than-ever-before/?sh= 24e709662bcf (accessed October 30, 2021).

Yulfo-Soto, G. E., Smith, H., Szarka, D., Dixon, E., Vaillancourt, L. J., and Gauthier, N. (2021). First report of Fusarium graminearum causing flower blight on hemp (Cannabis sativa) in Kentucky. Plant Dis. doi: 10.1094/PDIS-06-21-1292-PDN

Zelenay, A. (1960). Fungi of the genus Fusarium occurring on seed and seedlings of hemp and their pathogenicity. Prace Naukowe 2, 248-249.

Zhang, G.-L., Feng, Y.-L., Song, J.-L., and Zhou, X.-S. (2018a). Zearalenone: a mycotoxin with different toxic effect in domestic and laboratory animals' granulosa cells. Front. Genet. 9:667. doi: 10.3389/fgene.2018. 00667

Zhang, Q., Chen, X., Guo, H., Trindade, L. M., Salentijn, E., M. J., et al. (2018b). Latitudinal adaptation and genetic insights into the origins of Cannabis sativa L. Front. Plant Sci. 9:876. doi: 10.3389/fpls.2018. 01876

Zhao, H., Xiong, H., and Chen, J. (2021). Regional comparison and strategy recommendations of industrial hemp in China based on a SWOT analysis. Sustainability 13:6419. doi: 10.3390/su13116419

Conflict of Interest: The authors declare that the research was conducted in the absence of any commercial or financial relationships that could be construed as a potential conflict of interest.

Publisher's Note: All claims expressed in this article are solely those of the authors and do not necessarily represent those of their affiliated organizations, or those of the publisher, the editors and the reviewers. Any product that may be evaluated in this article, or claim that may be made by its manufacturer, is not guaranteed or endorsed by the publisher.

Copyright (C) 2022 Gwinn, Hansen, Kelly and Ownley. This is an open-access article distributed under the terms of the Creative Commons Attribution License (CC BY). The use, distribution or reproduction in other forums is permitted, provided the original author(s) and the copyright owner(s) are credited and that the original publication in this journal is cited, in accordance with accepted academic practice. No use, distribution or reproduction is permitted which does not comply with these terms. 